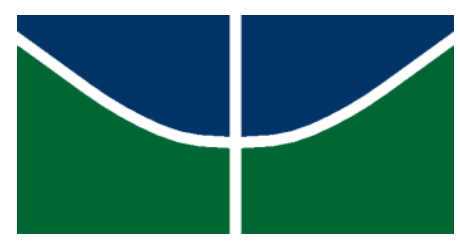

UNIVERSIDADE DE BRASÍLIA - UnB

FACULDADE DE EDUCAÇÃO - FE

DÉBORA OLIVEIRA SILVA

\title{
A INSERÇÃO DA EDUCAÇÃO POPULAR NO CONTEXTO DA EDUCAÇÃO DE JOVENS E ADULTOS: VISÕES DO CORPO DOCENTE
}




\title{
A INSERÇÃO DA EDUCAÇÃO POPULAR NO CONTEXTO DA EDUCAÇÃO DE JOVENS E ADULTOS: VISÕES DO CORPO DOCENTE
}

\author{
Trabalho de Conclusão de Curso \\ apresentado, como requisito parcial para \\ obtenção do título de Licenciada em \\ Pedagogia, à Comissão Examinadora da \\ Faculdade de Educação da Universidade de \\ Brasília.
}

Orientadora: Professora Doutora Maria Clarisse Vieira.

Brasília/DF 
SILVA, Débora Oliveira.

A INSERÇÃO DA EDUCAÇÃO POPULAR NO CONTEXTO DA EDUCAÇÃO DE JOVENS E ADULTOS: VISÕES DO CORPO DOCENTE.

- Brasília, 2017. 91pgs.

Trabalho de Conclusão de Curso - Universidade de Brasília, Faculdade de Educação, 2017.

Orientadora: Profa. Dra. Maria Clarisse Vieira

1. Educação de Jovens e Adultos 2. Educação popular 3.Docência 4. Saberes docentes 
DÉBORA OLIVEIRA SILVA

\section{A INSERÇÃO DA EDUCAÇÃO POPULAR NO CONTEXTO DA EDUCAÇÃO DE JOVENS E ADULTOS: VISÕES DO CORPO DOCENTE}

Comissão Examinadora:

Professora Doutora Maria Clarisse Vieira

Orientadora - MTC/FE - UnB

Professora Doutora BETÂNIA OLIVEIRA BARROSO

Examinadora - LCH/UFMA

Mestre em Educação STTELA PIMENTA VIANA

Examinadora - Secretaria de Educação - SEEDF 
"Tudo é considerado impossível até acontecer."

Nelson Mandela 


\section{AGRADECIMENTOS}

Eis que é chegado o momento de relembrar e agradecer de forma escrita às pessoas que semearam em minha vida até aqui. Minha gratidão plena a Deus, por me conceder a vida humana e a capacidade de vivenciar os desafios, prazeres, alegrias e tristezas, pois de tudo que há na Terra, são essas vivências que nos alimentam a cada segundo.

Agradeço à Nair Batista da Silva, minha mãe, que com seu jeito batalhador, me ensinou a batalhar firmemente. Em sua pessoa me espelhei, e à senhora dedico esta conquista, pois com a sua luta diária de faxinas e de serviços gerais, hoje sei o valor do suor de um trabalho e o preço que se paga pela falta de estudo.

Assim como à minha mãe, agradeço aos meus irmãos Daniel, Geovana e Gabriela, pela parceria. Sempre os cuidei como se fossem filhos meus enquanto minha mãe esteve fora trabalhando. Acredito que ouviram os conselhos de nossa mãe e trilharão um caminho digno de vitórias.

Agradeço à minha família materna e paterna pelo carinho, incentivo e ajuda nas horas de aflição. Ao meu pai, que apesar de ser um pouco ausente em minha vida, deixou lembranças de infância que também contribuíram para o que hoje sou.

Em especial, agradeço aos meus avós maternos, Maria Alena Batista da Silva e José dos Santos e Silva, pela fraternidade de cada abraço e pelo amor a terra, ao plantio, por terem ensinado aos netos e filhos a riqueza que a roça nos proporciona, agradeço pelo incentivo e por acreditarem em mim desde a infância. Por me darem comida quando não tive.

Agradeço aos professores do ensino fundamental, médio e de graduação, por demonstrarem profissionalismo e amor ao fazer docente, e que me mostraram entrelinhas a essência do que é ser professor, são eles: Professora Virgínia (2001), professora Natália (2003), professora Glória (2004), professor Gilson Izidio (20072008), professor Argeam Teles (2007), professor Teotônio Nunes (2009), professora Mara Cristina de Oliveira (2008-2009), Professor Juscelino Carvalho (2010).

Na graduação, professores (as): Dra. Maria Clarisse, Dra. Jacqueline Mendes,

Dr. Renato Hilário, Dra Gláucia Maria, Dra Rosângela Correia, Dr. Antônio Carlos (Instituto Fazer Social no DF) e Dra. Ireuda Mourão. 
Agradeço às amizades e às "colegagens" dos intervalos e trabalhos acadêmicos que estreitaram laços fortes e sinceros: Larissa Drago, Kely Martins, Ana Rosária, Sérgio Moreira, Prof. Fernando Alves, Fláesio Júnior, Fernanda Alkimin, Jakeline Vilela, Erika Oliveira, Cláudia Cipriano, Carla Leal, Jonathan Silva, Catherine Viana e outros que terão meu apoio se de mim precisarem. Não, estes nomes não estão em ordem de importância, todos são.

Em especial, agradeço à Ivana Vieira de Souza, amiga de graduação, à seu esposo Júlio César, ao filho André, por me darem atenção e zelo nas noites em que me cederam seu lar para que eu dormisse após voltar do estágio supervisionado em EJA no Paranoá. Que o universo lhes retornem lares tão acolhedores quanto o que você me ofereceu.

Gratidão à minha primeira supervisora de estágio, Raquel Rumeiro da ECT, que me ensinou as primeiras noções de competência profissional. Ao servidor do TJDFT Jonildo Menezes, meu segundo supervisor de estágio, por acreditar em mim, me mostrar a verdadeira simplicidade dos paraibanos e me orientar sobre os trâmites judiciais no processo que me possibilitou matricular na UnB a tempo.

Aos meus amigos de ensino médio que estão comigo até hoje: Naylane da Silva e Lorrane Santos.

Agradecimentos ao Departamento de Filosofia da UnB (professores e servidores), local onde estagiei por dois anos e que me conferiu um conhecimento maior acerca do funcionamento da $\mathrm{UnB}$ tornando minha visão desta, em toda a sua complexidade, para além da visão discente.

Agradeço também à Diretoria de Desenvolvimento Social da UnB - DDS, pela prestatividade e prontidão ao me receber enquanto aluna do Grupo 1. Obrigada pelo suporte e pela efetividade ao executarem a Política Nacional de Assistência Estudantil PNAES.

Agradecimentos ao GENPEX/UnB - Grupo de ensino-pesquisa-extensão em Educação Popular, Estudos Filosóficos e Histórico-culturais, do qual fiz parte por um ano e meio. Este me sensibilizou e alertou para a necessidade de uma educaçãoautônoma, política e acolhedora na Educação de Jovens e Adultos.

Agradeço também à Secretaria de Administração Acadêmica, SAA-PA-FE, e à Secretaria de Graduação pela excelência no atendimento aos estudantes. 
Obrigada a cada professor orientador das 37 disciplinas cursadas, 7 projetos, 1 projeto de iniciação científica e 4 monitorias realizadas, pela dedicação ao fazer docente, e pela melhoria teórico-prática de nosso país. Agradecimento especial para minha orientadora Professora Maria Clarisse, que superou todas as dificuldades da vida e chegou onde está. Não é por ter um título de doutora que se tornou superior aos seus alunos, obrigada por toda a paciência, compreensão, por manter a simplicidade e por cada exemplo dado ao longo desta caminhada comigo.

Minha gratidão ao universo e suas energias que me conduziram por este caminho e, agora, meu único pedido é permanecer forte até o fim dos dias. 


\section{RESUMO}

Historicamente, a educação de jovens e adultos foi acolhida por uma diversidade de propostas. Grande parte destas propostas foi permeada pela educação popular. Este trabalho de conclusão de curso foi desenvolvido com base na realização de uma proposta que relaciona princípios da educação popular dentro de uma instituição pública de ensino no Distrito Federal. A proposta acontece desde o segundo semestre de 2015, por meio da atuação do Grupo de Ensino-pesquisa-extensão em Educação Popular e Estudos Filosóficos-culturais- GENPEX, formado por professores e graduandos da Universidade de Brasília, e que advém de uma demanda do movimento popular do Paranoá desde a década de 1980. O objetivo geral deste estudo foi analisar em que medida a interação entre o modelo formal da EJA e da educação popular contribuem para a ressignificação da visão docente acerca da prática pedagógica desenvolvida. Adota-se como metodologia a pesquisa exploratória, por meio de entrevistas semiestruturadas junto a cinco professores que atuam na instituição escolar. $O$ trabalho aponta a construção de saberes docentes que mesmo sem formação específica para atuar na EJA e sem apropriação teórica do tema, vão ao encontro da essência da educação popular, evidenciando a força e potencialidade da mesma a partir da relação diária com os discentes e a prática desenvolvida pelo GENPEX/UnB.

Palavras-chave: Educação de Jovens e Adultos, Educação popular, avaliação docente, saberes docentes. 


\begin{abstract}
Historically, youth and adult education has been embraced by a diversity of proposals. Most of these proposals were permeated by popular education. This course completion work was developed based on the realization of a proposal that relates principles of popular education within a public educational institution in the Federal District. The proposal comes from the second half of 2015, through the work of the Teaching-research-extension Group in Popular Education and Philosophical Studiesculture- GENPEX, formed by professors and graduates of the University of Brasília, and which comes from a demand of the the popular movement of Paranoá since the 1980s. The general objective of this study was to analyze the extent to which the interaction between the formal model of EJA and popular education contributes to the re-signification of the teaching vision about the pedagogical practice developed. Exploratory research methodology is used as a methodology, through semi-structured interviews with five teachers who work in the school institution. The work points to the construction of teaching knowledge that even without specific training to act in the EJA and without theoretical appropriation of the theme, meet the essence of popular education, showing the strength and potentiality of the same from the daily relationship with students and practice developed by GENPEX / UnB.
\end{abstract}

Keywords: Youth and Adult Education, Popular education, teacher evaluation, teaching knowledge 


\section{LISTA DE ABREVIATURAS E SIGLAS}

ANPED - ASSOCIAÇÃO NACIONAL DE PÓS-GRADUAÇÃO E PESQUISA EM EDUCAÇÃO

CEDEP - CENTRO DE CULTURA E DESENVOLVIMENTO POPULAR DO PARANOÁ

CODEPLAN - COMPANHIA DE PLANEJAMENTO DO DISTRITO FEDERAL

DF - DISTRITO FEDERAL

D1 - DOCENTE 1

D2 - DOCENTE 2

D3 - DOCENTE 3

D4 - DOCENTE 4

EAD - EDUCAÇÃO À DISTÂNCIA

EJA - EDUCAÇÃO DE JOVENS E ADULTOS

GDF - GOVERNO DO DISTRITO FEDERAL

GENPEX - GRUPO DE ENSINO-PESQUISA-EXTENSÃO EM EDUCAÇÃO POPULAR E ESTUDOS FILOSÓFICOS E HISTÓRICO CULTURAIS DA UNIVERSIDADE DE BRASÍLIA

IBGE - INSTITUTO BRASILEIRO DE GEOGRAFIA E ESTATÍSTICA

INEP - INSTITUTO NACIONAL DE ESTUDOS E PESQUISAS EDUCACIONAIS ANÍSIO TEIXEIRA

LDB - LEI DE DIRETRIZES E BASES DA EDUCAÇÃO (1996)

MOBRAL - MOVIMENTO BRASILEIRO DE ALFABETIZAÇÃO

P - PESQUISADOR

SEDF - SECRETARIA DE EDUCAÇÃO DO DISTRITO FEDERAL

TERRACAP - COMPANHIA IMOBILIÁRIA DE BRASÍLIA

UNESCO - ORGANIZAÇÃO DAS NAÇÕES UNIDAS PARA EDUCAÇÃO 


\section{SUMÁRIO}

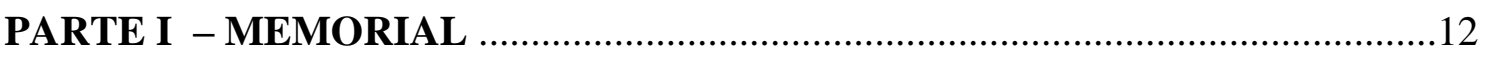

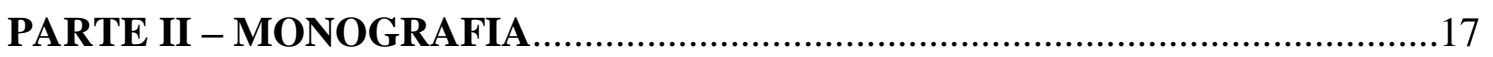

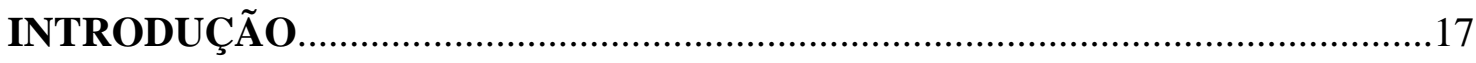

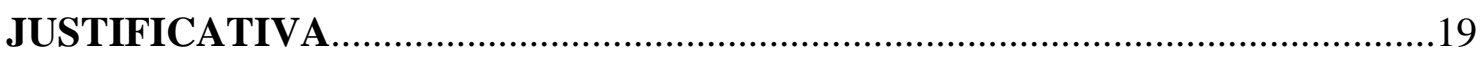

CONTEXTUALIZAÇÃO DO CAMPO DE PESQUISA ........................................20

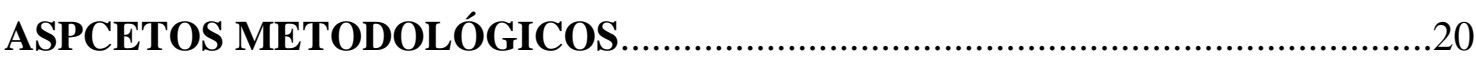

OBJETIVOS

1. A RELAÇÃO DA EDUCAÇÃO DE JOVENS E ADULTOS COM A EDUCAÇÃO POPULAR: FUNDAMENTOS E ASPECTOS HISTÓRICOS...............24

1.1 Os movimentos de cultura e educação popular e o diálogo com a camada diversificada e analfabeta ou com baixo grau de

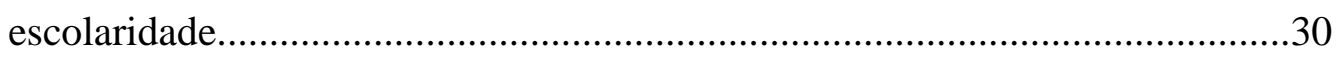

1.2 Bases epistemológicas da educação popular.....................................37

2- $\quad$ MANIFESTAÇÕES DA EDUCAÇÃO POPULAR: REPENSANDO

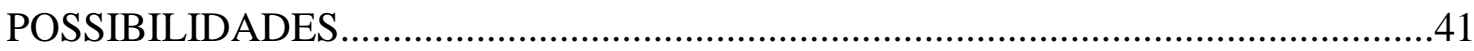

3- A PROPOSTA DESENVOLVIDA PELO GENPEX/UNB NA ESCOLA DE ADULTOS DO PARANOÁ: A EXPERIMENTAÇÃO QUE GERMINA UMA

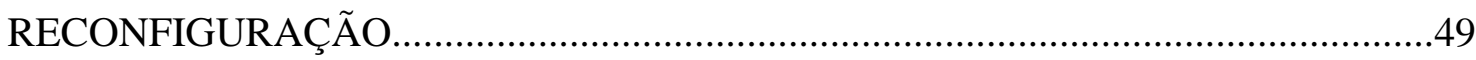

3.1 - A análise do corpo docente quanto à prática pedagógica desenvolvida pelo GENPEX: avaliações, significações e ressignificações do

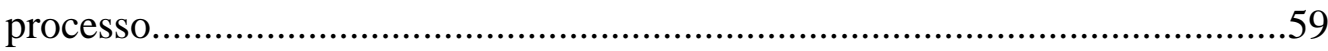

3.1.1 Perfil do docente com relação à EJA: Dimensão crítica.

3.1.2 Perfil do docente com relação à educação popular: Dimensão formativa experenciativa.

3.1.3 Análise docente da ação: a) Dimensão transformadora - quanto às transformações ocorridas no docente

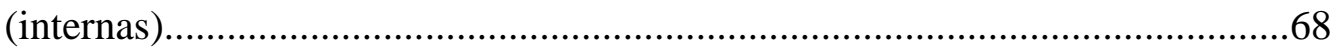

b) Dimensão transformadora: quanto às transformações percebidas nos

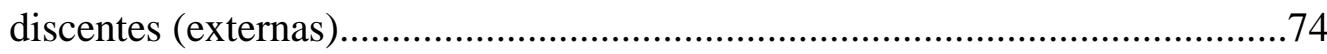

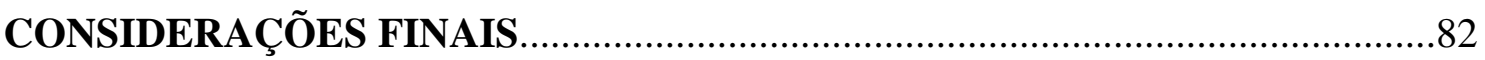


PARTE III -PERSPECTIVAS PROFISSIONAIS E PESSOAIS

.84

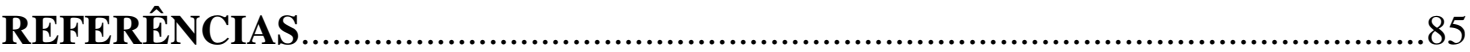

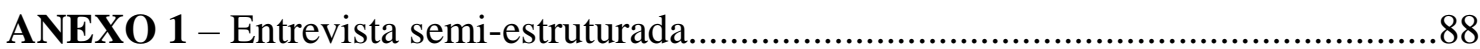

ANEXO 2 - Termo de consentimento livre e esclarecido..............................................89 


\section{PARTE I}

MEMORIAL

\section{PERCURSOS E PERCALÇOS DE MINHA HISTÓRIA}

MEUS PAIS VINDOS DO PIAUÍ

ERAM MAIS DOIS NO MEIO DE MILHARES

PROCURANDO NO QUADRILÁTERO

SUAS MORADIAS E UMA NOVA OPORTUNIDADE.

QUANDO AQUI CHEGARAM (1993)

A MORADIA TRATARAM DE ARRUMAR

NA INVASÃO DA ESTRUTURAL QUERENDO CASA

AS MADEIRITES VIRARAM O LAR.

UM EMPREGO DE DOMÉSTICA

UM EMPREGO DE VENDEDOR

ERA LUTA DIA A DIA

TUDO O QUE ELES QUERIAM

ERA UM FUTURO PROMISSOR

COM O TEMPO VEIO UMA FILHA...

DOIS... E TRÊS!

E A RENDA ERA TÃO POUCA

MEU DEUS, QUE SOFRIMENTO, MAIS UMA VEZ!

COM SAUDADE DO NORDESTE

OS FILHOS FORAM CRESCENDO

O DINHEIRO DA FAXINA

COMPRAVA O GÁS PRO ALIMENTO 
COM OS FILHOS NA ESCOLA,

A ESPERANÇA FOI AUMENTANDO

A VIDA DE OPORTUNIDADES

PARA OS FILHOS IA CHEGANDO

LICENCIATURA EM PEDAGOGIA

EU NEM SABIA DIREITO COMO ERA

SÓ SABIA QUE ERA ALGO SOBRE ESCOLA

SER PROFESSORA, TALVEZ... AH... QUEM ME DERA!

APROVADA PELO ENEM E APROVADA EM $14^{\circ}$

O ENSINO MÉDIO NÃO TINHA CONCLUÍDO

O PRAZO ESTAVA QUASE NO FIM

Ó DEUS, QUASE TIVE UM INFARTO.

COM MEU NOME NA LISTA

SEM DIPLOMA NÃO PODIA ENTRAR.

CORRE AQUI, E CORRE ACOLÁ

CONSEGUI NA JUSTIÇA, O DIREITO DE ME ADIANTAR

FIZ O AVANÇO DE ESTUDO, PROVA CONCEDIDA POR LIMINAR

APROVADA NO AVANÇO...

CORRE PARA SE REGISTRAR!!!

O ORGULHO DA FAMÍLIA

A MAIS VELHA PASSOU NA FEDERAL

VOU COMPRAR UM BOLO GRANDE

PARA ESTE MOMENTO ESPECIAL!

AO ESTUDAR PERCEBI QUE PEDAGOGIA

ERA MAIS QUE $A B C$

ERA POSSIBILITAR PARA OS ALUNOS

A LEITURA DO MUNDO É ALÉM DE LER E ESCREVER

HOJE AFIRMO QUE PEDAGOGIA 
FOI UMA GRANDE DESCOBERTA

FOI EXPLORAR A EDUCAÇÃO

PARA ALÉM DO QUE SE PREGA

ESTOU FORMANDO PROFESSORA

AGORA COM 22 ANOS

TALVEZ AINDA MUITO NOVA

MAS É DE NOVA QUE SE VAI LUTANDO

MINHA FAMÍLIA TODA SEM ESTUDO

QUE NOVIDADE ESSA MENINA SER DESTAQUE

QUE ELA POSSA CRESCER NA VIDA

E SER FELIZ NESSA CIDADE.

MAS LHE DIGO LOGO:

O SALÁRIO PRECISA SER SUFICIENTE

POIS NESSE SISTEMA, QUEM NÃO TEM

NÃO É GENTE!

HOJE, NÃO HÁ DINHEIRO QUE PAGUE

O SORRISO DO ALUNO CONTENTE.

AO ENSINAR E APRENDER

E DIZER O QUANTO SE ORGULHA DA GENTE!

VOLTANDO UM POUCO NO TEMPO,

MINHA MÃE ATÉ TENTOU ESTUDAR

EU A ACOMPANHAVA DURANTE A NOITE

OBSERVAVA TANTOS ADULTOS E IDOSOS

NINGUÉM NEM ABRIA A BOCA PRA FALAR

SERÁ PORQUÊ TANTO SILÊNCIO

CANSAÇO, FOME, MÃOS CALEJADAS DE CIMENTO

EU ERA PEQUENA MAS OBSERVAVA TUDO 
QUÃO DIFERENTE PRA MIM ERA AQUELE MOMENTO.

NA GRADUAÇÃO TIVE CONTATO COM A DISCIPLINA

A TEORIA E HISTÓRIA TROUXERAM-ME CONHECIMENTO

AGORA REALIZANDO PESQUISA CIENTÍFICA

PIBIC, PROJETO DE INTERVENÇÃO, ESTÁGIOS E ASSIM PERCEBENDO

A EJA NÃO É UM ATRASO, O POVO PRECISA DE RECONHECIMENTO

NÃO BASTA LIVROS E EXERCÍCIOS

O ADULTO JÁ SABE O QUE NO MUNDO ESTÁ ACONTECENDO

QUE TAL UM EDUCAÇÃO MAIS REAL

MAIS PRÓXIMA DO QUE ELES TÃO QUERENDO...

ASSIM COMO EM MINHA FAMÍLIA

ANALFABETISMO E IMPOSSIBILIDADE DE ESTUDAR

RONDAM MILHÕES NESTE PAÍS

E SE A EJA É UM DIREITO DELES

NA ESCOLA ELES DEVEM ESTAR

MAS NÃO É UMA TAREFA FÁCIL

E É SOBRE ISSO QUE VOU AGORA FALAR! 


\section{PARTE II \\ MONOGRAFIA}

\section{INTRODUÇÃO}

Este trabalho de conclusão de curso visa discutir a relação do fazer pedagógico da EJA no contexto escolar, com princípios da Educação popular imbricados em sua prática pedagógica, sob a perspectiva docente. Esta prática está situada dentro de uma parceria histórica - desde a década de 1980 - entre o movimento popular do Paranoá, região administrativa do Distrito Federal e o GENPEX/UnB (Grupo de ensino-pesquisaextensão em Educação Popular e estudos filosóficos e histórico culturais da Universidade de Brasília) desenvolvida na Escola de Adultos ${ }^{1}$, localizada também na mesma região.

A parceria da Universidade de Brasília com o movimento popular do Paranoá teve início com a luta para a permanência dos migrantes que no DF estavam, personagens do êxodo rural na década de 1970 e 1980. O Governo do Distrito Federal (GDF) à época adotava como estratégia de manutenção do projeto Plano Piloto a retirada de operários que residiam próximo à Brasília. Diante da luta pela moradia, pela sobrevivência e melhoria das condições de vida, os grupos preocupados com as condições dos assentamentos e acampamentos ganharam espaço, chegaram à presidência da Associação de moradores do Paranoá e continuaram com o enfrentamento ao governo, à TERRACAP, e às forças policiais para a conquista da fixação no espaço que em que contribuíram com suas forças de trabalho.

Este grupo estava decidido a se fixar e a receber o tratamento devido, o mínimo de respeito por terem contribuído na construção da capital federal. Mas as dificuldades de enfrentamento eram para além da resistência às bombas e explosões na tentativa governamental de os expulsarem do local, estavam para além das forças físicas. Perceberam a necessidade de uma força encontrada na cultura letrada. Ansiavam por uma formação educativa inicial dos moradores, para que pudessem ter um discurso mais claro e objetivo ao lidar com as autoridades e fortalecer os membros da chamada Vila Paranoá.

\footnotetext{
${ }^{1}$ Nome fictício dado à escola pesquisada.
} 
Com o fim do MOBRAL em 1985, a demanda pela alfabetização ainda era grande nas regiões do país. Este grupo então, em 1986 procurou a Faculdade de Educação da UnB na tentativa de ter auxílio nas habilidades de cálculo, leitura e escrita, e mais do que isso: como lutar para alcançar seus objetivos, serem reconhecidos como sujeitos históricos de direitos e deveres. O grupo posteriormente se fortificou e hoje é conhecido como CEDEP - Centro de Cultura e Desenvolvimento Popular do Paranoá, que realiza fóruns e participa ativamente na resolução de problemas comuns da cidade.

Em 1986, a professora da Faculdade de Educação, Dra. Marialice Pitaguari aceitou a parceria, e as ações de alfabetização de cunho popular voltada para a realidade imediata daqueles sujeitos se iniciam, com auxílio de professores, alunos e outros profissionais. Em 1989, o professor Dr. Renato Reis assume o grupo de ações da Faculdade e, em 2000 cria o GENPEX, composto por graduandos, mestrandos, doutorandos, professores da SEDF e outros pesquisadores e profissionais de educação. Ao longo da trajetória desta parceria, foram criados numa perspectiva freireana os fóruns de espaço de ação-reflexão-ação onde alfabetizandos, alfabetizadores, representantes da $\mathrm{UnB}$ e dirigentes do movimento popular delimitam quais são as situações-problema-desafio enfrentadas na comunidade, caracterizando como um processo democrático de fala, escuta de cada sujeito da comunidade (SOBRAL; REIS, 2017).

Esta práxis perdurou ao longo dos anos. Em 2016, o professor Renato Hilário se aposenta e a professora Dra. Maria Clarisse, assume a coordenação do GENPEX e as respectivas ações do grupo que já estava inserido no espaço formal da EJA em uma escola pública. $(2011)^{2}$.

A história foi permeada pela originalidade da educação, pois se iniciou de uma luta real para a aquisição e significação do conhecimento, foi e ainda é um processo de aprendizagem unida às iniciativas populares, o que se torna muito mais significativo para os jovens, adultos e idosos envolvidos nessa trajetória.

Mas é importante considerar que não se exclui dentro desse contexto de construção coletiva, os saberes sistematizados cientificamente, até porque a educação

\footnotetext{
${ }^{2}$ Para consultar as origens deste movimento recomenda-se a leitura de REIS REIS, R. H. dos. A Constituição do Ser Humano: amor, poder e saber na alfabetização de jovens e adultos. Campinas: Autores Associados, 2011.
} 
popular se vale também de conhecimentos advindos destes. Mas o diferencial da educação popular é que o foco é primeiramente no sujeito e suas necessidades cotidianas, em sua formação humana que produz sua própria identidade:

\begin{abstract}
A troca de conhecimentos, valores, sensibilidades, que implica uma formação do sujeito aprendiz como um ator crítico, criativo, solidário e participante, recria e recobre a experiência da educação cidadã. Quando essa alternativa de trabalho pedagógico - não necessariamente escolar - é criada por grupos sociais de trabalhadores, a experiência da educação, toma no dizer de seus praticantes, a identidade da educação popular. (BRANDÃO, 2003)
\end{abstract}

\title{
JUSTIFICATIVA
}

Atualmente existem cerca de 3,4 milhões de pessoas matriculadas em EJA no Brasil (INEP, 2016). Número expressivo, mas pequeno considerando o total de analfabetos que está em torno de 12,9 milhões (IBGE, 2016). Segundo o Censo Escolar (INEP) mais recente de 2016, as matrículas de EJA no Brasil relativas ao primeiro segmento (séries iniciais), diminuíram de 1.127.077 no ano de 2008 para 628.393 no ano de 2016. O decréscimo foi grande: 44,24\%. Cabe destaque para o fato de que a matrícula em EJA ser opcional, ou seja, em oito anos as pessoas procuraram menos a EJA. Em primeiro momento pode-se pensar: isso é bom, pois elas estão conseguindo aprender no tempo "correto", sem precisar procurar o período noturno. No entanto, não seria prudente pensar nessa perspectiva, pois metade desse número de analfabetos está acima dos 60 anos, também segundo o IBGE. Onde estão estas pessoas? Por que a procura está diminuindo? A EJA é um espaço que realmente afirma o sujeito e seu direito?

O trabalho se justifica na necessidade de uma abordagem integral de educação que considere o sujeito da EJA como protagonista do processo de ensino-aprendizagem, tornando o processo mais acolhedor, cativante, que seja antes de tudo, "ferramenta" crucial na conquista e na permanência desses estudantes em sala. Essa abordagem é tão necessária, pois as trajetórias desses estudantes até hoje não se descomplicaram, não estão mais fáceis em relação ao passado (ARROYO, 2005).

Como marca do público composto pelas classes populares e perfis nítidos de gênero, raça e etnias diversos, a educação popular pode contribuir progressivamente 
nessa abordagem, transfigurando-se na prática pedagógica da Educação de Jovens e Adultos dentro da escola.

$\mathrm{Na}$ perspectiva de se realizar um trabalho conjunto que dialoga com as atividades das disciplinas curriculares administradas pelos professores, o GENPEX/ UnB atua por dois anos desde 2015 com uma equipe de profissionais de educação, universitários, e movimento popular, elaborando discussões teóricas e práticas com a equipe gestora e tentando aproximação com a equipe docente da escola relatada. $\mathrm{O}$ contato, as aproximações, as proposições, reflexões e construções caminham para um planejamento conjunto e abrangente que tenta flexibilizar a prática promovendo o princípio humano de educação ainda que no espaço institucional e sistematizado disciplinarmente. A tentativa é amenizar o enrijecimento de uma prática para adultos que começou com pilares da libertação e acolhimento nas dinâmicas populares do século passado.

\section{CONTEXTUALIZAÇÃO DO CAMPO DE PESQUISA}

Quanto às características socioeconômicas da região onde a escola se situa, segundo a última pesquisa realizada pela CODEPLAN (2015), compõe-se de cerca de 48.020 habitantes, com renda média de \$2.691,00 e per capta de \$ 868,48. Quanto ao nível educacional possui cerca de $4 \%$ de analfabetos e somente $3.85 \%$ com nível superior completo. Quase metade possui nível fundamental incompleto $(43,94 \%)$ e 18,29 \% com nível médio completo. A instituição atende no período diurno as séries iniciais do ensino fundamental e à noite de 19h às 22h, oferece Educação de jovens e adultos. Segundo estatísticas do ano corrente, atua com 6 turmas, distribuídas entre $1^{\text {a }}$, $2^{\mathrm{a}}, 3^{\mathrm{a}}$ e $4^{\mathrm{a}}$ etapas, equivalentes ao primeiro segmento, e 138 alunos matriculados. Com mais de um semestre de atividades, o nível de desistência dos alunos corresponde a 19\% do total de matrículas (27 alunos).

\section{ASPECTOS METODOLÓGICOS}

Trata-se de uma pesquisa exploratória, que segundo Gil (2008), proporciona maior familiaridade com o problema de pesquisa, buscando através de uma abordagem 
qualitativa investigar e discutir como os docentes se situam nesse processo de transição de modelo pedagógico. Quanto ao procedimento técnico, foi adotada a pesquisa de campo, que procura o aprofundamento de uma realidade específica. Constitui-se em uma avaliação realizada por meio de entrevistas com informantes, para captar as explicações e interpretações do que ocorre naquela realidade (GIL, 2008). Como instrumento de produção de dados foi elaborada uma entrevista semiestruturada composta por cinco perguntas, registradas as respostas por meio de gravação de voz, que serviram de roteiro para aprofundar algumas dimensões, as gravações foram posteriormente transcritas integralmente para análise.

Foram convidados a participar da entrevista cinco professores ( duas mulheres e dois homens), um de cada turma ofertada e um professor da escola que atualmente também é coordenador. Quatro convidados aceitaram e uma professora negou a participação argumentando que não teve convivência o suficiente com a EJA e com o GENPEX para poder avaliar, pois estava atuando na EJA há poucos meses.

Quanto ao registro das entrevistas, não houve uniformidade no processo, pois um dos docentes não permitiu gravação e os registros foram por meio de anotações. Outra docente não teve tempo disponível para que gravássemos e sugeriu o envio dos depoimentos via-email. Todos os sujeitos pertencem ao corpo docente noturno do quadro de servidores da SEDF, efetivos (1) e temporários (3), que participam ou já participaram das práticas desenvolvidas pelo GENPEX/UnB na Escola de Adultos.

\section{OBJETIVOS}

Como objetivo geral pretendeu-se analisar em que medida a interação entre o modelo formal da EJA e da educação popular contribuem para a ressignificação da visão docente acerca da prática pedagógica desenvolvida.

E para chegar a este objetivo geral percorreram-se os seguintes objetivos específicos:

1. Contextualizar o processo de implantação da proposta de educação popular em uma escola pública que oferta EJA;

2. Analisar como foi/é a participação docente neste processo de inserção da educação popular na EJA;

3. Analisar as significações atribuídas deste processo de inserção, no corpo docente da escola; 
Para alcançar os três objetivos, o trabalho foi estruturado em três capítulos que buscaram primeiramente a partir de uma abordagem histórica da EJA, observar a relação da educação voltada para jovens e adultos com a educação popular, explicitando alguns fundamentos epistemológicos. Após perceber essa relação, o capítulo seguinte traz uma discussão sobre o conceito de educação popular que supera a visão de práticas informais imbricadas no campo da Sociologia, ditas exclusivas para classes populares, também para estas, mas não exclusivamente. O capítulo seguinte relata a experiência desenvolvida pelo GENPEX-UNB como uma forma atual de transformação do espaço institucional a nível pedagógico e analisou a perspectiva do docente da educação formal que participou ou participa desta reconfiguração e da flexibilização da lógica rígida e centrada em conteúdos desconexos das experiências de vida dos sujeitos.

Nessas considerações o trabalho percorreu os objetivos específicos chegando na compreensão final de como esta experiência impactou e ressignificou a postura e a prática desses docentes do sistema institucionalizado da EJA, que por vezes demonstra uma atuação metódica e estática em grande parte do sistema educacional. Assim foram sistematizados os capítulos:

1. A relação da Educação de Jovens e Adultos com a educação popular: fundamentos e aspectos históricos;

1.1 Os movimentos de cultura e educação popular e o diálogo com a camada diversificada e analfabeta ou com baixo grau de escolaridade;

1.2 Bases epistemológicas da educação popular;

2. Manifestações da Educação popular: repensando possibilidades;

3. A proposta desenvolvida pelo GENPEX/UnB na Escola de Adultos do Paranoá: a experimentação que germina uma reconfiguração;

Desejamos ao leitor uma excelente leitura! 
"Não há que ser forte. Há que ser flexível." 
Provérbio Chinês

\section{A relação da Educação de Jovens e Adultos com a educação popular: fundamentos e aspectos históricos}

Na história da educação brasileira é impossível afirmar que todos os brasileiros tiveram direito à educação ofertada pelo Estado da mesma forma e na mesma proporção. Portanto, para entender o panorama e a justificativa da existência da Educação de Jovens e Adultos na atualidade, é preciso nos remeter à nossa história educacional, observando que as gerações que nasceram e viveram nas épocas primárias do país receberam pouca ou nenhuma educação no seio formal e que, somente nas últimas décadas parte destes, puderam receber uma oferta escolar que possibilitasse o acesso ao conhecimento acumulado pela humanidade, registrado na letra da lei, o que representa um avanço notável. Para essa retomada histórica o capítulo discute aspectos das obras de Vieira (2004), Arroyo (2005) e Ribeiro (1993), entre outros autores.

Com a progressiva extensão do direito à educação e ampliação de escolas, as gerações seguintes foram adentrando a educação formal, mas ainda vivenciando as defasagens qualitativas do processo de consolidação da educação, que aos poucos se aperfeiçoava - e assim continua - e, ao mesmo tempo, lidando com as dificuldades de sobrevivência existentes em maior grau nas camadas populares.

A constituição da educação no país foi marcada pela precariedade, oferta seletiva, e insuficiente. Ainda vivemos as consequências desse projeto colonizador. Basta observar os dados quali-quantitativos recentes das pesquisas nacionais. Um dado relevante segundo os indicadores sociais do IBGE é a afirmação da existência de 12,9 milhões de analfabetos. Indo mais a frente, atente-se para o fato que mais da metade desse número está acima de 60 anos. Mais a frente, 4,4 milhões tem entre 40 e 59 anos. E desse total, 342 mil pessoas somente, tem menos de 24 anos. Ora, o menor percentual é pertencente a uma geração mais atual que em relação às gerações mais velhas, tiveram seus processos escolares mais discutidos e estruturados.

Em que época essas pessoas viveram que não puderam estudar na chamada idade apropriada? Cabe pensar em como estava o país neste período. Sabendo que a educação tem poder influenciador de geração, qual foi a educação que seus antepassados tiveram? Se tiveram, que influências receberam? Tem-se aí a repetição de 
uma cultura silenciada e não reflexiva quanto aos processos societários justamente por não terem tido o acesso a uma educação de qualidade e emancipatória.

Reportando aos primeiros séculos de escolarização no país, tratou-se de uma escolarização essencialmente religiosa que se seguiu com instruções mínimas voltadas aos interesses do Estado, e fracas reformas no tocante à maioria da população. Esta maioria era ocultada dentro do projeto de manutenção do sistema sócio-político e econômico da época.

Segundo Vieira (2004), no período imperial, por se tratar de uma sociedade de base agrária e escravocrata, não havia necessidade de uma educação escolar, o que denota uma história educativa excludente, pois também nesse período o mais expressivo exercício cidadão à época: que era o voto democrático, era restrito aos de maior poder econômico. Quanto à oferta do ensino elementar e secundário, a repartição das competências nas poucas escolas da época, tornou-se precária quando o Ato Adicional de 1834 atribuiu às províncias a responsabilidade do desenvolvimento destas, e ao governo Imperial, o ensino das elites (VIEIRA, 2004). Essa repartição de oferta básica ficou precarizada, pois essas unidades eram as que detinham menos recursos no período. Ainda segundo a autora, no período da colônia à Primeira República:

As iniciativas concretas em prol do desenvolvimento do ensino elementar foram raras, esparsas e descontínuas, atingindo um pequeno número de educandos. (idem, p. 13)

Em 1890, o censo apontava cerca de 85,2\% da população maior de 5 anos na condição de analfabeta, 30 anos depois, em 1920 esse número ainda era alto, 72\% da população na mesma faixa ainda era analfabeta (VIEIRA, p.13). Esse dado revela que o problema no analfabetismo no Brasil é estrutural, e o que se vive hoje são resquícios dessa organização tardia e descontínua que veremos a seguir.

Foi somente nos anos 20 do século passado que a educação começou a ser modificada e discutida de forma mais abrangente, após o declínio das oligarquias, a crise do modelo agrário-comercial-exportador e o impulso industrializador do período nacional-desenvolvimentista (RIBEIRO, 1993). Nesse período, segundo Ribeiro, as evoluções ocorreram para que o projeto de desenvolvimento nacional fosse estimulado através de uma escolarização mais estruturada: 
(...) surge um movimento de cunho pedagógico, a Escola Nova. Veremos, pela primeira vez, educadores de profissão que denunciam o analfabetismo e outros problemas da educação. O escolanovismo vai buscar na Europa suas origens, onde já no século anterior uma sociedade industrializada se preocupava com a individualidade do aluno. No Brasil, os pioneiros da Escola Nova defendem o ensino leigo, universal, gratuito e obrigatório, a reorganização do sistema escolar sem o questionamento do capitalismo dependente, enfatizam a importância do Estado na educaçãoe desta na reconstrução nacional. Como solução para os problemas do país, apelam para o humanismo científico-tecnológico, ou seja, convivência harmoniosa do homem com a máquina, criando-se condições para que os indivíduos convivam com a tecnologia e a ciência, fazendo-os entender que tudo isto está a serviço e disponibilidade do homem. (p. 19, 1993, grifo nosso)

Ainda que o Escolanovismo tenha gerado discussões relevantes, nem tudo foi resolvido. A despeito dos avanços deste movimento, o que se delineava era uma educação voltada exclusivamente para indústria, sem se considerar a qualidade do sujeito do processo. Segundo Brandão (2003), esse momento de democratização do ensino e seus personagens envolvidos foram embriões do que mais tarde seriam os movimentos populares. Do outro lado, situava-se o embate da igreja católica com os pioneiros da educação, o que gerou uma intensa discussão sobre quais princípios regeriam a educação diante do novo projeto da onda de industrialização. Em 1930, surge o Ministério da Educação e Saúde e em 1934, pela primeira vez tem-se um capítulo dedicado à educação na Constituição Federal, o que trouxe uma substancial organização para as práticas educativas formalizadas.

Alguns educadores como Anísio Teixeira e Fernando de Azevedo trouxeram para o Brasil, ideais do filósofo John Dewey - filósofo e pedagogo norte-americano, defensor do modelo progressivo de educação - e Ribeiro chama atenção para o fato da desigualdade: a estrutura de indivíduos era muito desigual, pois havia uma intensa relação de um grupo dominante e um grupo dominado, ideais americanos ou europeus poderiam não ser os mais adequados no momento a nível qualitativo:

A influência dos escolanovistas foi marcante, e a ação de educadores como Fernando de Azevedo e Anísio Teixeira, trouxe para a realidade educacional brasileira, idéias e técnicas pedagógicas dos Estados Unidos da América, representadas pela filosofia educacional de John Dewey. Um aspecto negativo do pensamento dos pioneiros é que a realidade brasileira era totalmente adversa da realidade americana ou europeia. (p.22, 1993, grifo nosso) 
Esses pioneiros perceberam as lacunas existentes e tentaram melhorias no campo da educação. Com o Estado Novo e mudanças estruturais ocorrendo no mundo, o Brasil aumentou as verbas destinadas à educação, mas o foco era quase que estritamente formar mão de obra competente para o mercado de trabalho.

Neste período, já se pode relatar algumas experiências de modelos de uma educação voltada para os adultos de camadas populares. No Distrito federal, Vieira (2004) dá destaque ao trabalhado iniciado por Pascoal Lemme, em 1933 a 1935 educador e administrador na rede pública de educação. Eram cursos elementares realizados e articulados aos cursos de continuação e aperfeiçoamento, que eram instalados próximos aos locais de trabalho, residências ou associações de classe. A iniciativa foi interrompida em 1935 com a prisão de Pascoal acusado por envolvimento comunista. Pode-se observar que as ações voltadas à educação de adultos atingiram um número pequeno de indivíduos devido à abrangência curta e interrompida por dinâmicas político-partidárias do país.

Na era Vargas (1930 a 1945), houve mudanças significativas na sociedade. Em 1934, a Constituição Federal também estabelece a criação do Plano Nacional de Educação e pela primeira vez designa para o Estado, o dever de ofertar a educação de adultos (VIEIRA, 2004). Nos anos que se seguiram, a educação de jovens e adultos passa a ser tratada com uma notoriedade e perfil de política pública. Para fomentar essa discussão estrutural do analfabetismo, a autora destaca em sua obra, algumas iniciativas como:

\footnotetext{
1938: Criação do instituto nacional de Estudos Pedagógicos que incentivava estudos voltados para a educação de jovens e adultos;

1942: Criação do Fundo Nacional de Ensino Primário FNEP, com a finalidade de ampliar e melhorar o sistema escola primário em todo o país; 1945: Regulamentação do FNEP estabelecendo que $25 \%$ dos recursos deveram ser aplicados na educação primária de adolescentes e adultos analfabetos observando os termos de um plano geral de ensino supletivo aprovado pelo MEC e Saúde;

Organização do serviço de educação de adultos, do Departamento Nacional de educação. (p. 17, 2004)
}

Seguindo a ambientação mundial da época, com o impulso industrializador o país viu a necessidade de incluir a massa popular nos processos formativos de qualificação mínima. Na década de 40 , criou-se os serviços que ofertavam uma 
educação mais rápida e prática para operariado, exemplo dessa estratégia: o SENAI. Em 1946 criou-se o SENAC, semelhante ao SENAI, entretanto com foco em atividades comerciais.

Após 1945, com fim do Estado Novo, o país passa por uma redemocratização e o ensino primário passa a ter uma renovação juntamente ao ensino normal conforme os princípios do Manifesto dos pioneiros ${ }^{3}$.

Nos anos 1950 houve novamente uma discussão sobre quais ideais nossa educação deveria seguir. A ideologia católica defendia a extinção das escolas públicas por considerá-la falha, comunista e contrária a Deus. Como forma de atender aos dois interesses maiores, a Lei de Diretrizes e Bases da Educação de 1961 consegue a junção desses dois olhares para a educação: permanecem escolas confessionais privadas e permanecem as escolas públicas, laicas e gratuitas - duas ideologias basicamente educavam o povo brasileiro. Na década de 50 , as grandes campanhas de educação de adultos e de educação rural começam a surgir, entre elas:

1- Campanha de Educação de Adolescentes e Adultos (CEAA, em 1947): Campanha que atuou em duas frentes: urbana e rural. Visava a redução do analfabetismo com fins eleitoreiros, para dar capacidade de voto ao grupo participante. Aliada à expansão da rede de ensino primário regular e supletiva, essa campanha em sua vigência, reduziu os índices de analfabetismo no Brasil (em 1960, 39,5\%), mas recebeu críticas quanto a atuação do voluntariado, baixo preparo e remuneração, condições precárias e inadequação de materiais didáticos;

2- Campanha Nacional de Educação Rural, de 1952 a 1963: Por meio da criação de missões rurais, o ministério da educação e da Agricultura pretendeu levar uma educação de base para o meio rural, com o auxílio de profissionais pertinentes ao campo e focalizando na formação de líderes rurais e criação de centros comunitários, clubes de jovens, de mães, etc;

3- Campanha Nacional de Erradicação do Analfabetismo, CNEA: O grupo de técnicos do INEP Buscou de maneira experimental através de um projeto inicial em Leopoldina, Minas Gerais, desenvolver ações para a melhoria da qualidade do ensino primário e posteriormente ampliar para o âmbito nacional. Seus organizadores compreendiam que a mera ação alfabetizadora era insuficiente devendo conferir prioridade à educação de crianças e jovens as quais a educação ainda poderia signifcar alteração em suas condições de vida. Em 1963 a campanha se encerra, marcando uma nova etapa sobre a ação educativa no que concerne à atuação da união na educação de adultos. (VIEIRA, p. 22, grifo nosso)

A Educação de jovens e adultos começava a ser discutida e ser desenvolvida

\footnotetext{
${ }^{3}$ Manifesto dos Pioneiros da Educação Nova. Refere-se a um documento escrito por 26 educadores, em 1932, com o título A reconstrução educacional no Brasil: ao povo e ao governo. Circulou em âmbito nacional com a finalidade de oferecer diretrizes para uma política de educação.
} 
com a participação do estado, mas ainda assim em iniciativas insuficientes e em pequena abrangência.

Com a presença maciça de analfabetos, os movimentos populares também desempenharam um importante papel na tentativa de incluir esse grupo na sociedade tanto no aspecto sócio-cultural, mas principalmente na participação política e decisiva dos diversos espaços e problemas em que essas pessoas se encontravam.

O Público da EJA era e ainda é formado principalmente por jovens, adultos e idosos trabalhadores, mulheres e negros componentes de classes baixas. Portanto, as iniciativas populares eram as abordagens que mais problematizavam essas condições, que visavam dessilenciar estes sujeitos, deixavam com que falassem e fossem ouvidos, experenciando um momento inicial político numa democracia proporcionada em grande parte da história, fora da sala de aula, nos espaços possíveis para reuniões populares.

Enquanto se discutia e se experimentava os possíveis pilares da educação nacional advindas de outros sistemas educacionais estrangeiros, chamo atenção aqui para a originalidade desse movimento. Não foi uma prática educativa influenciada em peso por modelos externos, foi uma expressão própria, pura, íntima, que trazia a reação da maioria populacional diante de uma estrutura de estado que não pretendia integrar todos os cidadãos de forma justa ou menos desigual no tocante à oferta das oportunidades.

Esses movimentos também eram constituídos de cunho cultural: levaram arte e entretenimento cultural à classe trabalhadora junto às práticas de alfabetização e incentivo à participação de adultos na política. Tinha-se no Brasil algumas facetas divergentes ao que o Estado planejava.

Nos períodos seguintes persistiu o modelo americanizado principalmente através dos acordos do MEC com a Agency for International Development (AID)conhecidos como MEC-USAID. É importante pensar aqui a respeito da identidade da educação brasileira, especialmente para o perfil de jovens, adultos e idosos já investidos no mundo do trabalho com experiência de vida bastante formada, trajetórias escolares ausentes ou truncadas, e com objetivos e perspectivas diferentes.

A originalidade do movimento popular é fundamental para pensarmos as contribuições deste para o desenvolvimento integral não só de educandos enquanto educandos, mas de educandos enquanto cidadãos, no sentido amplo de pessoa, e, principalmente trabalhadores de classe baixa, visto que é grande maioria no país. 
Nesse sentido, a Educação de jovens e adultos tem um perfil claro de público, e tem as iniciativas populares como fontes principais e mais próximas que acolheram e compreenderam essa parcela da população desde o início da história educacional do Brasil. Abaixo veremos alguns exemplos destas iniciativas.

\section{1 - Os movimentos de cultura e educação popular e o diálogo com a} camada diversificada e analfabeta ou com baixo grau de escolaridade

$\mathrm{Na}$ linha de pensamento humanista e qualitativo, com base na Pedagogia libertadora de Freire, e na concepção histórico-crítica de desenvolvimento humano, preocupado com o sujeito em seu momento e meio, as ações e contribuições do movimento de Educação Popular não foram poucas. E através das diversas práticas pedagógicas fica superado o mito de que a alfabetização por si só promove o desenvolvimento social e pessoal, esse mito há muito tempo foi desfeito (VIEIRA, 2004).

Segundo Arroyo (2005), o campo da educação de jovens e adultos sempre carregou em sua história, a marca da diversidade de identidades coletivas de classe, gênero, raça, etnia, aberto a todo cultivo e onde vários agentes participaram até o início de sua institucionalização. Com o empenho de estudos mais cuidadosos, a visão de uma educação assistencial, efetuada por meio de campanhas e improvisação começa a ser superada revelando um campo inovador pedagógica e politicamente (ARROYO, 2005, p. 32).

No trato com a educação, a América Latina antecede essa abordagem no Brasil, iniciada na década de 1960 mais notadamente no Nordeste brasileiro. Inicia-se um movimento originário dos diferentes grupos da sociedade (Grupos estudantis, organizações políticas, associações religiosas, com projetos sociais alternativos) visando aproximação às camadas populares utilizando a educação para legitimar suas propostas (VIEIRA, 2004). Frisa-se o termo "propostas", por compreender que esses movimentos não eram um projeto só, com um objetivo apenas e sim uma gama de iniciativas que foram rondando as camadas populares.

O temor de que o Brasil pudesse ser o palco de uma segunda revolução socialista, ativou os grupos políticos para ampliarem as bases eleitorais motivando ações educativas aos grupos populares (VIEIRA, 2004). Nesse período, alguns grandes 
movimentos tiveram destaque por estarem representando as condições sociais e econômicas da época - da grande massa popular - e por isso, estavam enraizados com o cotidiano real da classe em questão. Desta forma, por compartilharem a paridade na luta e emancipação política dos sujeitos, e visarem transformações sociais pode-se considerar uma relação íntima e comprometida com a classe jovem, adulta e idosa, reconhecendo esses indivíduos como indivíduos de direitos e deveres e não apenas mão de obra qualificada ou que viria a ser potencialmente qualificada.

Os movimentos populares foram fortemente desenvolvidos principalmente na década de 1960 tornando-se uma estrutura de emancipação para a camada popular, analfabeta e de baixa renda, incluindo nesse perfil, negros e seus descendentes em vários pontos do país que anos após a libertação da condição escravista, ainda enfrentavam a busca pelo mercado de trabalho visto que não tinham a formação adequada e sentiam na micropolítica diária o mito da democracia racial (PASSOS, 2010).

Destacaram-se os principais movimentos:

MCP - Movimento de Cultura Popular do Recife: Criado em 1960, na gestão de Miguel Arraes, sem espaço próprio e como principal meta de governo, a promoção da educação. As ações foram desenvolvidas utilizando diversos espaços como igrejas, templos, clubes, associações populares e outros. O trabalho era voltado para a conscientização das massas por meio da alfabetização e da educação de base. As ações se ampliaram e constituíram um programa de cultura popular: artesanatos, canto, dança, música, construção de praças, centros e parques de cultura. Nesse movimento, houve o lançamento do primeiro livro para adultos elaborado por Norma Coelho e Josina Godoy que tratava de palavras-chaves e situações de aprendizagem pautadas no contexto existencial dos educandos (VIEIRA, 2004).

CPC - Centro Popular de Cultura: de iniciativa da UNE (União Nacional dos Estudantes), foi criado em 1961 e posteriormente foram ampliados em outras regiões do país. Utilizava o teatro de rua, a música, a poesia, empregando na arte aspectos políticos relevantes àquele público popular.

MEB - Movimento de Educação de Base: Iniciado em 1961 através da Conferência Nacional dos Bispos do Brasil - CNBB. Essa conferência propunha ao presidente Jânio Quadros uma campanha de educação popular realizada através do 
rádio, caracterizando uma espécie de educação radiofônica. O MEB posteriormente passa a reforçar a politização e se aproxima do movimento de sindicalização rural. Com golpe militar de 1964, o MEB foi o único que resistiu por estar ligado ao MEC e à Igreja Católica, mas em 1966 grande parte dos sistemas MEB encerram as atividades por pressões e escassez de recursos.

SISTEMA PAULO FREIRE: Iniciado nos Círculos de cultura do MCP de Recife. Foi marcado pela experiência de Angicos, Rio Grande do Norte onde o idealizador da experiência, educador Paulo Freire, alfabetizou cerca de 380 operários em 40 horas. Embora pareça um processo rápido, a proposta de Freire é de base cristã e humanista e contou com uma elaboração preocupada com a conscientização e reflexão crítica sobre a realidade. Adotando o conceito antropológico de cultura, a valorização e recuperação da cultura popular, o método buscava levantar os vocábulos presentes no respectivo grupo e destrinchar dessas palavras, as demais formas de escrita e leitura, tendo como princípio fundante a discussão dialógica problematizadora da realidade social dos educandos em menor grau, visando à consciência de maior grau.

Esta experiência logo se popularizou e foi reproduzida em outros círculos populares. Em 1963, o Ministro da Educação Paulo de Tarso, solicitou a Freire que organizasse um projeto Piloto em Brasília e que elaborasse um Plano Nacional de Alfabetização. Mas os olhares governamentais lançados a esta experiência visavam também a nível quantitativo à formação de milhares de novos eleitores para 1965 (VIEIRA, 2004).

Assim como outras propostas ao longo do país, os movimentos de cunho popular foram tidos como subversivos por desencadear a mobilização política das classes baixas e tornaram-se alvos de repressão sendo interrompidas para darem lugar à novas formas de ensino e educação que não mobilizasse objetivamente as pessoas para reflexão e questionamento da estrutura de poder presentes nos espaços.

Logo após 1964 com o golpe de estado, esse movimento foi reprimido. Ainda segundo Ribeiro:

Era necessário afastar das decisões políticas e administrativas, os setores da sociedade que não comungavam com as mesmas ideias do governo, e o Brasil irá passar por um extenso período de repressão política, censura à Imprensa e aos outros meios de comunicação, reforço do Executivo, tortura a presos políticos, exílio voluntário ou não, de grandes nomes da Ciência e Educação (p.26, 1993) 
Com o golpe militar, as liberdades políticas foram reprimidas, e por isso a realização de práticas de educação popular foi afastada, lideres e organizadores do movimento popular também foram exilados. Entretanto, algumas ações diversificadas continuaram na EJA.

Em 1966, acontece a Cruzada ABC - Ação Básica Cristã dirigida por evangélicos norte-americanos com viés assistencialista que buscou ocupar a ação dos movimentos populares, mas por diversas críticas, uma delas pelo foco meramente alfabético, foi perdendo espaço até que se iniciasse o MOBRAL - Movimento Brasileiro de Alfabetização em 1967 (VIEIRA, 2004).

Em 1970, o MOBRAL adquire status de movimento nacional de maior impacto dos governos militares. Em 10 anos de atuação ainda havia segundo o censo do IBGE, cerca de $25,5 \%$ de pessoas analfabetas na população de 15 anos ou mais, quando a meta inicial era erradicar totalmente o analfabetismo. Em 1985, o programa se encerra com o fim do governo militar e é assumido pela Fundação Educar. Até o governo militar, pode-se dizer que a "tarefa" e a responsabilidade com a grande massa analfabeta foi realizada pelas seguintes organizações: Associações, ONGs, Instituições religiosas, movimentos e iniciativas populares, Campanhas, Planos e Programas nos diferentes níveis federativos e no governo militar em 1971, o status legal à época chamado de ensino supletivo, mas ainda não sendo competência exclusiva do estado, nem obrigatória para a população. Cabe pensar, nas disparidades de caráter das ações desenvolvidas pelas diversas organizações, um campo amplo, diverso, por vezes assistencialista, religioso, sem diálogo político e não bem delimitado quanto ao caráter da alfabetização inicial.

A organização do ensino supletivo através da Lei federal 5.692/71 estabelecia a organização de cursos acelerados, ensino profissionalizante, ensino EAD e exames de certificação. Em 1974 criaram-se os CES - Centro de Estudos Supletivos - que pretendia escolarizar um número notável de analfabetos mas com foco basicamente quantitativo, e segundo Vieira (2004) mediante um baixo custo operacional satisfazendo as necessidades de um mercado de trabalho competitivo com exigências crescentes de escolarização.

Já na década de 1980, com o fim do governo militar, a elaboração da constituinte, o MOBRAL também chega ao fim em 1985. Este, é substituído pela Fundação Educar, que passa a assumir a estrutura nacional e cria o Programa de 
Educação Básica, que duravam 1440 horas distribuídas em dois anos. Ainda nesse contexto, a EJA é reconhecida finalmente como um direito na Constituição Federal de 1988, e a educação passa a ter uma maior importância do campo legal e das políticas subsequentes levando em consideração também as contribuições e lutas dos movimentos populares de luta por direitos e práticas educativas. A fundação Educar é extinta em 1990 logo após a obrigatoriedade da oferta de EJA ter passado para o estado nas esferas municipais e estaduais.

Nas décadas seguintes a EJA continua sendo tratada por mais Planos e programas nacionais diversos como por exemplo:

A) O MOVA - Movimentos de Alfabetização realizados em algumas áreas do país, e iniciado em 1989, pelo partido dos Trabalhadores em São Paulo. Os movimentos eram políticas públicas de parceria dos governos municipais e organizações comunitárias, que tinham em suas práticas princípios da educação popular nos moldes freireanos.

B) Plano Nacional de Alfabetização e Cidadania - (PNAC) - Iniciado e interrompido em 1992, pelo governo Collor;

C) Programa de Alfabetização Solidária - (PAS) - Lançado em 1996, vinculado ao governo federal, mas com característica de ONG, previa uma visão restrita de alfabetização, em 5 meses e com fraca estrutura de formação docente e sem perspectiva de prosseguimento de estudos dos educandos;

D) Plano Nacional de Formação do Trabalhador (PLANFOR) Concebido em 1995 pelo Ministério do trabalho e com foco na qualificação para o trabalho;

E) Programa Nacional de Educação na Reforma Agrária (PRONERA): Criado em 1998 através da união do Conselho de Reitores das universidades brasileiras (CRUB), o Movimento de trabalhadores sem Terra, o INCRA (Instituto Nacional de Colonização e Reforma Agrária).

F) Programa Brasil Alfabetizado: iniciado no governo Lula em 2003 e ainda vigente, novamente com a meta de se erradicar o analfabetismo do Brasil em quatro anos. Em 2003, firmou cerca de 37 convênios e atingiu cerca de 1768 municípios baseados na diversidade de metodologias de EJA 
já existentes e registradas no país. As críticas não são diferentes: o programa também foi questionado pelo tempo de efetividade da meta e pela formação do educador que estaria atuando.

É importante destacar algumas discussões de eventos científicos internacionais como, por exemplo:

A) Conferencia mundial de educação para todos em 1990 na Tailândia: No evento o Brasil tornou-se signatário da Declaração Mundial de Educação para Todos onde adultos também eram incluídos nas metas de melhorias de 155 países. No Brasil a EJA em decorrência desse compromisso é referenciada no Plano de Educação Decenal em 1993 e no Plano Nacional de Educação em 2001 .

B) V Conferência Internacional de Educação de Adultos - V CONFINTEA: Realizada em 1997, na Alemanha. Os compromissos firmados após este evento, que acontecem a cada 12 anos, foram pensados de maneira ampliada, tratando a EJA como um direito consumado no princípio de valorização da terceira idade e visão de um sujeito histórico e aprendiz também na terceira idade:

Ela abarca uma multiplicidade de processos formais e não formais de educação e aprendizagem ao longo da vida, transcendendo os marcos escolares e desenvolvendo-se em várias esferas da vida social. (...) Como consequência desta visão ampliada, superou-se a perspectiva compensatória da EJA, introduzindo um novo sentido às práticas de EJA: Aprender a conhecer, aprender a ser, aprender a fazer e aprender a conviver. Uma importante contribuição desse evento foi enfatizar que a educação de adultos é um direito, sendo a chave de entrada para o século XXI. (p.74)

C) Conferência de Dakar, Senegal em 2000: O encontro visou avaliar o quanto de progresso havia ocorrido desde a assinatura da Declaração Mundial de Educação para todos em 1990 e constatou-se que nenhuma nas metas foi cumprida na integralidade. Segundo Vieira (2004), havia no ano 2000 mais de 113 milhões de crianças sem acesso ao ensino primário e 880 milhões de adultos analfabetos. Diante dessa avaliação foi elaborado o 
Marco De Ação de Dakar onde foi reafirmada a perspectiva da Declaração Mundial comprometendo todos a alcançar as metas até o ano de 2015.

D) VI Conferência Internacional de Adultos, em Belém do Pará, pela primeira vez sediada no Brasil, 2009: Convocado e organizado pela UNESCO, o evento contou com uma Conferência Regional LatinoAmericana Preparatória a VI Confintea que ocorreu no México, além de encontros regionais e estaduais para discutir o diagnóstico e os desafios da educação de jovens e adultos em cada país. As considerações deste evento foram quanto à progressiva extensão do direito ao acesso e permanência, oferta da EJA integrada à profissionalização, formação específica para educador e gestor de EJA, supressão do exame de certificação que empobrece a formação do sujeito entre outras recomendações para os próximos 10 anos, até 2020.

A participação do Brasil nesses acordos mundiais refletiu bastante nas últimas décadas, refletindo na Lei de Diretrizes e Bases da Educação Nacional. Apesar do avanço na CF/1988 que reconheceu a EJA como parte da Educação básica, o artigo 38 da LDB ainda trazia uma visão compensatória, que era entendida como "a falta de", o que denotava uma visão de atraso, de fracasso e falha, quando na verdade são pessoas em grande parte, vítimas de uma série de ações descontínuas ou inexistentes no início da estruturação educativa. Numa análise mais profunda feita no cenário internacional e na movimentação teórica nacional, a EJA deve ser entendida como um direito dessas faixas etárias, não como um caráter de suplência.

Outro marco importante que refutou esse caráter supletivo de mera compensação, foram as diretrizes curriculares de EJA. Elaboradas pelo Conselho Nacional de Educação em 2000, através do parecer $n^{\circ} 11$, retoma a história da EJA e confere a compreensão de um direito subjetivo atribuindo-lhe três funções importantes: Função reparadora, equalizadora e qualificadora que considera o caráter de incompletude do indivíduo e considera a formação tanto em idades escolares ou não escolares.

Considera-se então que o desenvolvimento da EJA enquanto direito e garantia é recente. As discussões de todas as instituições, nos diferentes níveis federativos, no 
campo internacional, das diversas práticas, experiências, contribuíram para a diminuição dos números de pessoas sem acesso à escolarização. No entanto, o aspecto qualitativo também necessita caminhar junto, caso contrário formam-se pessoas que sabem ler, escrever, calcular, mas incapazes de realizar pensamentos mais complexos, subjetivos e sem consciência de conexão de si e do outro numa sociedade que cada vez mais fragiliza os laços e processos de conscientização em detrimento de uma lógica estritamente tecnológica, individualista, desconectada e despreocupada em grande parte com perspectivas humanistas.

\section{2 - Bases epistemológicas da Educação Popular}

Sabendo quem são os sujeitos pertencentes às camadas populares antes e agora, os dispositivos legais e culturais que vetaram o ingresso de tal camada à educação no percurso histórico do Brasil, e a inovação no campo pedagógico que o movimento de educação popular demonstrou, discutem-se a seguir, aspectos relacionados às suas bases epistemológicas a sua prática pedagógica.

Nas últimas décadas com a crescente discussão acadêmica de temas didáticos, sociais, culturais e pedagógicos, a EJA foi enriquecida com a criação dos fóruns de EJA no Brasil (1997), inclusão de disciplinas do campo nos cursos de licenciatura, grupos e encontros nacionais de discussão teórica como, por exemplo, o Grupo de Trabalho n. 18 da Associação Nacional de pós-graduação e pesquisa em educação -ANPED. A partir de 2003, O governo federal e órgãos auxiliares reuniram-se e consideraram essa discussão para referenciar a educação popular nas políticas públicas nacionais.

Neste processo, foi utilizado o Marco de Referência da educação popular para as políticas públicas, publicado recentemente em 2014. Após o $1^{\circ}$ Seminário Nacional da Política de Educação Popular em 2013 que buscou integrar o Governo Federal, os movimentos sociais, as universidades, educadores populares, e da educação formal brasileira com a realização de consultas públicas por meio de portais digitais, iniciou-se uma discussão organizada pela Secretaria Geral da Presidência da República que gerou o documento trazendo em seu processo de elaboração a própria marca do que se discutia: a participação popular. O documento buscou: 
Resgatar o importante papel que a Educação Popular desempenhou historicamente na formação do povo brasileiro, bem como dá destaque para a sua relevância e contribuição no modelo de desenvolvimento, reconhecendo que a ação estatal e seus processos educativos podem confluir em um fértil campo de diálogo com a realidade, entre os saberes e o conhecimento acumulado do povo brasileiro (p. 6)

Partindo do pressuposto de que no processo de gestão há um processo educativo e formativo implícito, a educação popular torna-se um ato político (não partidário) que ouve, escuta, discute e respeita os diversos personagens do processo. A educação popular se concretiza então, não somente no trato aos analfabetos, como também no processo de elaboração das próprias políticas públicas, na tentativa de evitar a verticalização comum das decisões institucionais. Seguem os princípios balizadores destacados no documento oficial:

a) Dialogicidade: fundamento da Pedagogia libertadora de Freire, é defendida por Brandão (2003) como uma das principais contribuições da educação brasileira no campo de teorias pedagógicas fora do Brasil. Esse fundamento não é específico da prática educativa mas de toda ação política que busque pensar um problema, problematiza-lo e resolvê-lo. Nesse sentido, não há na perspectiva popular, uma fala mais importante que a outra, as relações de diálogo são paritárias, todas as falas são úteis ao processo educativo, aproveitando-se nas narrativas, elementos constitutivos do saber para construir um novo saber. Educadores populares e as classes populares devem oportunizar a reconstituição simbólica do real, elaborando alternativas para a superação das compreensões fatalísticas a respeito do que se passa na vida cotidiana (p. 37).

b) Amorosidade: $\mathrm{O}$ documento ainda se referindo aos princípios freireanos de educação, aponta a amorosidade como portadora da dimensão de alteridade. Trata-se de considerar as diferenças no processo de aproximação e não de universalização/homogeneização. Segundo Freire (2002), o ato de amar é se comprometer com a causa, amar o mundo, a vida, aos homens/mulheres. 
c) Conscientização: Significa ultrapassar a apreensão da realidade e chegar a uma esfera crítica onde o homem assume uma posição epistemológica. Não se disse qual posição, é aí onde está a chave da libertação: conhecer a realidade, compreender, se apropriar e assumir um posicionamento. A conscientização está então, ligada à capacidade de desvelamento da realidade:

\begin{abstract}
A consciência ingênua se apoia em uma visão simplista sobre a realidade e prefere exaltar o passado como referência para dizer o que é o melhor. Além disso, é impermeável à investigação e, portanto, frágil na discussão aprofundada dos problemas; a verdade é imposta e seu apelo tem forte impulso passional. Dessa forma, a realidade é estática e imutável. (2014, p. 40 e 41)
\end{abstract}

$\mathrm{Na}$ população com baixo grau de escolaridade escolar esse pensamento é bastante presente. Uma compreensão ingênua, sem necessidade de aprofundamento ou investigação. A verdade que chega é a que fica, a que se torna justificativa para os problemas aparentemente iguais, uma visão simplista e que não mudará: porque é assim. Considero este o principal fundamento da prática com as camadas populares, é necessário desenvolver essa postura, não ensinar, mas praticá-la em todo processo educativo para que não se aprenda a fazer, mas que se aprenda, fazendo. É preciso principalmente e sobretudo, deixar que se pense, que conheça, que escute, que compare, que fale e que aja sobre a realidade.

d) A transformação da realidade e do mundo: Todo processo dialógico e conscientizador se confundirá com alguma espécie de transformação do meio. Podem ocorrer tanto movimentos contrários quanto potencializadores das relações econômicas, sociais, culturais, ambientais, baseadas na igualdade, na fraternidade e na justiça (p.42). Mudando as relações, mudam-se as relações de interpretação e compreensão entre as dinâmicas humanas de comportamento como por exemplo: egoísmo, individualismo, sexismo, preconceitos e discriminação. Não mudando estas, podem pelo menos serem amenizadas se trabalhadas no processo de constituição humana.

e) Partir da realidade concreta: A realidade não é um dado aleatório. A realidade concreta é o próprio campo de ação-transformação, é onde está inserido o sujeito transformador. Fica claro o objetivo da educação popular, 
romper com a prática conteúdista, e priorizar o vínculo e relação com o contexto diário e vivido pelos adultos educandos. É importante prestar atenção nesse rompimento conteúdista, até porque os sujeitos dessa educação tem direito de se apropriar do conhecimento científico já existente. Trata-se de organizar a relação da realidade com os conteúdos. Um adulto busca uma educação significativa, é primordial a conexão entre conteúdo, saberes não científicos acumulados e experiência de vida. É primordial se enxergar essa relação e principalmente de sentir-se autônomos sobre o meio em que vivem e viverão.

Considerando a realidade, considera-se também a diversidade de sujeitos da educação popular, ainda segundo o Marco de referência da Educação Popular de 2014:

A Educação Popular não apenas reconhece essa alteridade, mas assume a afirmação das identidades e das diferenças e as reconhece como componentes da própria diversidade sociocultural. (p. 49)

\section{f) Construção do conhecimento e pesquisa participante: Neste} fundamento, valoriza-se no processo educativo a relação entre teoria e prática. Ao mesmo tempo em que se age em determinado meio, se modifica o meio e o pesquisador e, se produz pesquisa, se produz a teoria pautada na prática de ação-reflexão. Neste processo, a pesquisa:

\footnotetext{
é o instrumento que viabiliza, mediado pelo diálogo, o aprofundamento da temática em estudo e a produção do novo saber. Sem a atividade de pesquisa, ensino-aprendizagem e aprendizagem-ensino, tanto por parte do educador e da educadora quanto por parte do educando e da educando, e, apesar das especificidades dos papéis, ambos estão em contínuo processo de ensinar e aprender. (p. 45)
}

Nesse sentido, nas práticas de educação popular o docente, ou melhor, o educador é também pesquisador. A todo o tempo ele está pesquisando, conhecendo, refletindo e agindo sobre a realidade em que estiver atuando.

g) Sistematização de experiências e do conhecimento: Nesse fundamento é adotada a visão do ser inacabado e da constante construção do conhecimento. Dessa forma, a chamada Pedagogia da educação popular defende o aprofundamento e recriação da própria concepção de educação popular. Cabe 
aos educadores e líderes em educação popular pensar e reformular os projetos políticos pedagógicos da ação educativa em diferentes espaços e tempos. Não é conferida à educação popular a qualidade de estática, pronta, perfeita e acabada. É flexível conforme seus próprios fundamentos de dinâmica e alteridade (BRASIL, 2014).

O documento reflete sobre a ressignificação da Educação popular atualmente observando princípios históricos e direcionando as perspectivas não somente para a prática em EJA, mas diretrizes que promovem o desenvolvimento do sujeito também na elaboração de políticas públicas. O próximo capítulo irá discutir esta nova cara da educação popular que têm aparecido em outras dinâmicas de processos participativos e formativos, a partir das considerações de Brandão (2008).

\section{2 - Manifestações da Educação popular: repensando possibilidades}

Ao pensar a educação popular e suas manifestações diversas ao longo da história, Brandão (2003), aponta quatro interpretações das produções científicas quanto ao tratamento e a indagação da existência ou não dessa educação atualmente. As mais frequentes são:

A primeira postura, que destina-se àqueles que negam a educação popular como uma tendência, metodologia, sistema, filosofia ou uma forma de organização. Nessa postura, a educação popular é vista como um "desvio ideológico, pobre e ocorrida marginalmente no Brasil e na América Latina" (p.20).

A segunda postura reconhece uma relevante importância da educação popular para a cultura, mas define uma ligação mais voltada para o campo do movimento social do que para a educação propriamente dita. Pelo fato de essas práticas se darem em grande parte fora dos limites de uma escola, aparecem com mais frequência nos estudos da Sociologia dos movimentos. Essa justificativa também se dá pela interpretação que estes grupos conferem à educação, que, segundo o autor, se a educação não é espaço de questionamentos, então para quê tratar a educação popular como algo relativo à educação: A educação é o lugar da competência, não o da militância (...) O lugar da profissão, não da política. (BRANDÃO, 2003, p. 21) 
A terceira postura a compreende como um fenômeno datado e situado na década de 1960, iniciados no Brasil. Mas conflitando com essa postura, o autor também chama atenção para o fato de que em todos os continentes existir alguma modalidade de militância através da educação popular e argumenta que na própria Alemanha existem mais Institutos Paulo Freire que no Brasil, enfatizando que o legado da educação popular é mais considerado no exterior. Ora, então é preciso pensar... Ainda existe? ou realmente ficou datado e situado na década de 1960 ?

E por fim, a quarta postura, que é a que ele se situa e a que norteia este trabalho. Esta confere à educação popular uma história mais longa e diversificada. Compõe-se de idas e voltas em relações pedagógicas de teor político que enxerga os sujeitos como protagonistas emergentes de um processo. Trata-se da defesa de um estilo de educação e uma sequência de ideias:

Trata-se de uma tradição acontecida no passado em vários momentos e que hoje se abre às mais diferentes leituras críticas, entre educadores e outras pessoas ocupadas em compreender fenômenos humanos e culturais. Uma tradição em curso agora, nesta virada de milênio, e - como outras tantas vocações da educação - aberta às múltiplas e complexas alternativas do futuro. (BRANDÃO, 2003, p. 24)

Partindo da defesa da existência atual da educação popular, e considerando suas diversas expressões, pode-se destacar algumas manifestações na trajetória educativa nacional afirmando suas gêneses, como por exemplo: escolas anarquistas para operários e seus descendentes em bairros operários de São Paulo, do Rio de Janeiro e Rio Grande do Sul, no fim do século XIX e começo do XX, a própria luta pela escola pública e gratuita através (também) dos Comitês Pró-liberdade de consciência, que segundo o autor conferiam a participação de pastores, espíritas, maçons, militantes socialistas e intelectuais. Além do surgimento de grêmios estudantis, ações da Igreja Católica, de sindicatos e outras representações, na década de 1960.

A possibilidade de representação de vozes diversas em um processo e espaço comum, ainda é presente em dinâmicas atuais, mas também em espaços institucionalizados e mais recentemente como Brandão destaca, nas administrações municipais e estaduais atualmente no país, estas, recebendo nomenclaturas como: administração popular, governo democrático, escola cidadã, constituinte escolar ou projeto político pedagógico, orçamento participativo, conselho escolar, entre outros. 
Nessas nomenclaturas e em seus processos de gestão e organização, estão pressupostos de participação, escuta, fala convergente e divergente, representação e debates de diferentes sujeitos com objetivos em comum, o que começa a se aproximar das práticas recorrentes do movimento popular, o desenvolvimento e preocupação com as partes componentes do momento.

Nesse sentido, a concepção de educação popular é repensada antes de indagar a sua existência ou não. O conceito dessa educação para o autor é na verdade, o que ele chama de vocação. Não é definida como uma tendência ou escola pedagógica isoladas em tempos e espaços históricos diferentes, nem como uma proposta metodológica rígida. E é considerando a vocação da educação popular que se pode afirmar a atualidade dela nos mais diversos espaços que se iniciaram no fim do século XIX, século XX e percorreram até o presente. Um exemplo recente é o Marco de Referência da Educação Popular para as Políticas Públicas no Brasil, já citado aqui, (Presidência da Republica, 2014) que reconhece os fundamentos dessa vocação como pressupostos na elaboração das políticas públicas em geral com maior participação social e inclusão, não somente de educação. Nesse sentido o autor entende a educação popular como uma educação que tem vários nomes:

\footnotetext{
A educação popular diz o seu nome. Seria melhor dizer os seus nomes, pois ao longo de sua trajetória e agora mesmo, em nossa época, ela é, ao mesmo tempo, frágil e múltipla. (...) Essa vocação da pedagogia não foi uma experiência única de um momento na história do Brasil, na América Latina ou em outros cenários do mundo (...) isso a que damos o nome de educação popular aparece em momentos sucessivos e em cenários diversos (BRANDÃO, p. 42)
}

Diante dessa multiplicidade de cenários, polissemias e interpretações, existem traços recorrentes nas práticas e iniciativas de diferentes segmentos civis que utilizaram a educação popular para alcançar diferentes objetivos, e que definem a essência, ou melhor, essa vocação (ou uma espécie de intencionalidade e rumo da ação, como autor explica). Dentre eles: o desenvolvimento de identidades e não de aparências, a mobilização individual e coletiva, a alternativa educativa, a politização, a escuta associada ao diálogo, o compromisso de todos os personagens, e a capacidade de análise e reelaboração de realidades próximas e projeções longínquas. Esses princípios dão à educação popular um significado muito mais abrangente, ligada à teologia da libertação e muitas vezes ligada à esquerda política. Mas nesse sentido, ele destaca também que 
não necessariamente a vocação precisa estar ligada a um partido ou ideologia centralizadora, embora aconteça em grande parte das práticas:

Não era de sua competência, nem era sua vocação propor ideologias, antecipar políticas e estabelecer programas populares de ação social. (BRANDÃO, p. 39)

O que se visa no processo é justamente a libertação - inicialmente do pensamento e ação dos sujeitos - fundamentos divergentes da vocação empresarial dos processos de escolarização comuns e massificadores.

Em uma segunda análise, pedagogicamente pensando, as práticas abarcam diferentes metodologias e formas de trabalho, mas fortemente pautadas nos princípios anteriores e desta forma, assumem a identidade da educação popular. Nos anos 1960, em que se é muito discutido o método Paulo Freire, é importante considerar que ele é apenas uma das manifestações, a mais notável e mais contributiva, talvez.

Juntamente à discussão da constituição da educação popular, tem-se o crescimento de eventos científicos, a divulgação no exterior e o advento da pesquisa participante que fornece instrumentos para a consolidação teórico-prática desse campo de estudo, mas que ainda tem um lugar liminar, superficial ou inexistente nas universidades brasileiras (Brandão, 2003). É reconhecida, portanto, a presença da dimensão pedagógica, mas não isolada. O fator trabalho está imbricado a outras dimensões e faz com que dialoguem os três pontos principais: cultura, política (não no sentido partidário) e pedagogia (no sentido da organização e realização prática do método). Assim, diz o autor:

Havia lugar, portanto, a toda uma dimensão cultural no trabalho político, assim como havia uma dimensão política no trabalho pedagógico, e para fechar o círculo uma dimensão pedagógica em todo o trabalho cultural. (p. 28)

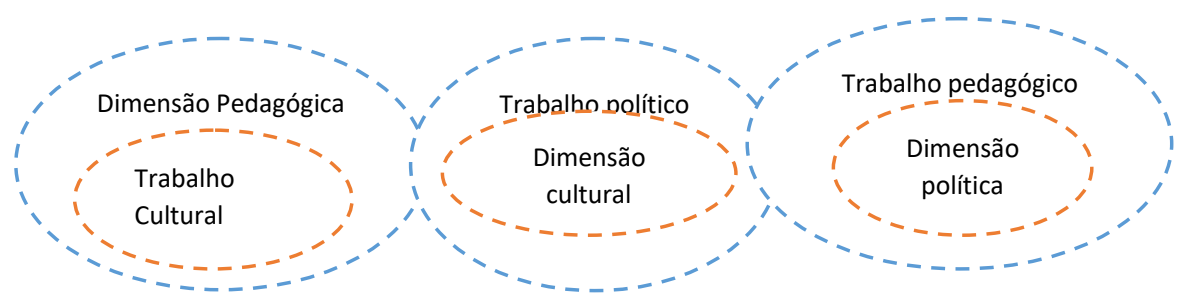

Esta forma de interligação de fundamentos é o que sustenta o sentido social do educador popular e que por meio das releituras atuais da educação popular, pode ser 
pensada, experimentada, reconfigurada, na formação e na atuação do campo docente no interior das escolas institucionalizadas de EJA e em outros níveis e modalidades de ensino com outras idades. Para o autor, a postura interior e profissional do educador, está para além do fazer docente, está para um compromisso consigo mesmo e com o sujeito dentro de um princípio humano e transformador de educação:

O termo educador popular era e segue sendo um termo de identidade de várias pessoas que se reconhecem como agentes de educação, mesmo quando não estão atuando em salas de aula. (p.34)

Quando se fala de educação popular, geralmente remete-se ao pensamento a uma interpretação de práticas em ambientes não formais ou informais, sem eixos principais, sem sistematização ou base didática, o que traz uma desvalorização, julgada frequentemente pelo adjetivo informal como ações desorganizadas e sem elaboração pedagógica, quando na verdade o norte da educação popular tem um sentido, que é a preocupação com processos formativos e não meramente ocupacionais do sujeito participante do processo, seja ele de classes subalternas, ou em outras classes e instituições onde se tenham momentos de construção coletiva e tomada de decisões democráticas. Tomemos como um exemplo mais próximo e atual, o modelo de gestão democrática das escolas públicas do Distrito Federal. Instituído pela Lei 4.751/2012, o modelo descentraliza as decisões hierárquicas e confere à escola uma maior centralidade incluindo progressivamente os diferentes protagonistas. A lei também determina instrumentos de participação, construção e decisão, como por exemplo:

I - órgãos colegiados:

a) Conferência Distrital de Educação

b) Fórum Distrital de Educação;

c) Conselho de Educação do Distrito Federal;

d) Assembleia Geral Escolar;

e) Conselho Escolar;

f) Conselho de Classe;

g) grêmio estudantil;

II - direção da unidade escolar.

Além de apresentar também princípios fortemente ligados ao conceito abordado em questão da educação popular:

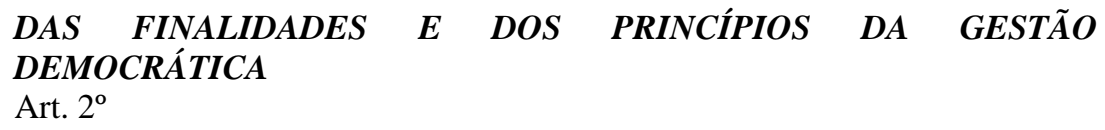


A gestão democrática da Rede Pública de Ensino do Distrito Federal, cuja finalidade é garantir a centralidade da escola no sistema e seu caráter público quanto ao financiamento, à gestão e à destinação,observará os seguintes princípios:

I - participação da comunidade escolar na definição e na implementação de decisões pedagógicas, administrativas e financeiras, por meio de órgãos colegiados, e na eleição de diretor e vice-diretor da unidade escolar;

II - respeito à pluralidade, à diversidade, ao caráter laico da escola pública e aos direitos humanos em todas as instâncias da Rede Pública de Ensino do Distrito Federal;

III - autonomia das unidades escolares, nos termos da legislação, nos aspectos pedagógicos, administrativos e de gestão financeira;

IV - transparência da gestão da Rede Pública de Ensino, em todos os seus níveis, nos aspectos pedagógicos, administrativos e financeiros;

$\mathrm{V}$ - garantia de qualidade social, traduzida pela busca constante do pleno desenvolvimento da pessoa, do preparo para o exercício da cidadania e da qualificação para o trabalho;

VI - democratização das relações pedagógicas e de trabalho e criação de ambiente seguro e propício ao aprendizado e à construção do conhecimento; VII - valorização do profissional da educação.

Destaque para as palavras e trechos: caráter público, implementação de decisões pedagógicas, administrativas e financeiras, democrática, participação da comunidade escolar, eleição, respeito, pluralidade, diversidade, caráter laico da escola pública, direitos humanos, autonomia, aspectos pedagógicos, transparência, qualidade social, exercício da cidadania, trabalho, relações pedagógicas, democratização, construção do conhecimento, valorização. Essas palavras fundamentam o modelo de gestão institucional revelando uma proximidade com as preocupações da educação popular, agora no contexto mais moderno afirmando a existência da educação popular novamente, como um norte atual de gênese nas classes populares e não como um momento isolado do passado.

A significação da educação popular defendida pelo autor supera a ligação com movimentos sociais, o que não significa que ela se desfaz destes, estão ligados, mas atualmente aparece como já dito, em outros cenários e outras configurações. O que acontece é que os movimentos populares são desenvolvedores de educação popular e esse desenvolvimento também pode ser feito por outros personagens e espaços.

Agora pensemos: os órgãos colegiados não garantem a representação dos diversos protagonistas que compõe as atividades meio e fim? Não exercitam periodicamente um exercício político? Não ouvem e dialogam com sujeitos populares? Pais, alunos, servidores, funcionários e participantes da comunidade escolar em geral? Não preveem uma composição diversificada? Todo esse processo está em vigência, e nessa concretização há a essência e princípios da educação popular, com outro nome, 
com outra cara, mas promovendo uma formação emancipadora e política no ato do exercício e semelhante a outras experiências distribuídas no Brasil, esta, porém, definida em lei.

Ainda que seja uma obrigação de fazer, pode - se afirmar que a educação popular norteia tanto em processos não-formais quanto na elaboração de diretrizes públicas. Trata-se, portanto, de uma manifestação da educação popular no contexto no DF que é sustentada pela própria constituição Federal de 1988. Esta também é conhecida como constituição cidadã, por ter participação do povo em sua elaboração e por aumentar as considerações com camadas anteriormente excluídas. Em seu artigo 206:

Art. 206. O ensino será ministrado com base nos seguintes princípios:

VI - gestão democrática do ensino público, na forma da lei;

Ao compreender que o significado de educação popular está para além de práticas informais e mais voltado principalmente para o ato de educar de forma popular, as possibilidades e formatos que aparecem a partir dessa compreensão não são poucas. Giovanetti (2005) concorda com Brandão ao relatar as experiências pelo Brasil do que ela chama de "escolarização popular": "é o caso de Belo Horizonte, com a proposta da Escola Plural; Blumenau com a escola Sem Fronteiras e Brasília, com a Escola Candanga; e outras que se apresentam em comum a proposta política marcada pela preocupação da oferta de uma escolarização como direito de todos (Vieira, 2015, p. 246)

Considerando as contribuições e abordagens deixadas pelas várias experiências e pelo visionamento da educação popular, é importante pensar se ela tem espaço diante da institucionalização e formato atual da EJA. Vale ressaltar que na ausência da oferta pelo sistema, esse público não foi atendido. E quando ocorre a presença de oferta a esse direito, o sistema atende por muitas vezes de forma engessada, incompreensiva e homogeneizadora. Dessa forma, que contribuições a educação popular poderia deixar ao sistema atual e ao público de EJA?

Segundo Arroyo (2005), tentar adequar a realidade imediata dos estudantes atuais de EJA com o sistema escolar não será fácil. A educação popular dentro do 
conceito ampliado e sua capacidade de flexibilidade e reflexão nos trazem uma importante e destacada contribuição para esta tarefa que ainda está em discussão.

As abordagens educativas são revistas e modificadas ao longo dos tempos para que se afirme o direito e a efetividade da educação. As formas de organização precisam aproximar-se dos sujeitos reais o que indiscutivelmente torna o processo formativo integral e qualificado humanamente, além de proporcionar a dimensão política e cultural aliada ao conhecimento que a escola proporciona.

Os sujeitos da educação de jovens e adultos são caracterizados pela condição de não crianças, experiência de vida nas relações sociais diversas e complexas, histórico de exclusões, conhecimentos acumulados pelos sentidos, reflexões mais elaboradas, diferenças cognitivas (OLIVEIRA, 1999). Há ainda a ideia e sensação de atraso, autodesvalorização das faixas etárias mais avançadas e, principalmente no mundo do trabalho e por vezes, uma estrutura disciplinar, rígida, impositiva e hierárquica. Há que se acrescentar que por a oferta de EJA não ser obrigatória há um forte distanciamento desses estudantes de EJA do ambiente escolar. É conferido um direito que afirma, mas uma pratica que nega o sujeito e suas marcas. A EJA surge exatamente do não espaço nas estruturas amplas e formais (ARROYO, 2005), e é justamente por isso que as estruturas responsáveis atualmente devem dar este espaço aliado ao processo qualitativo de aprendizagem e formação humana que considere um contexto ampliado de sujeito e sujeito coletivo.

Nesse sentido, Arroyo também afirma a necessidade da busca de outros parâmetros próprios e específicos para esse público:

\footnotetext{
A superação de estruturas lógicas e seletivas, hierárquicas, rígidas, gradeadas e disciplinares de organizar e gerir os direitos ao conhecimento e à cultura é uma das áreas de inovações tidas como inadiáveis. Neste quadro de revisão institucional dos sistemas escolares, torna-se uma exigência buscar outros parâmetros para reconstruir a historia da EJA, se a organização dos sistemas d educação formal está sendo revista e redefinida a partir dos avanços da consciência dos direitos, a educação dos jovens-adultos e idosos tem de ser avaliada na perspectiva desses avanços. (p.44)
}

A revisão e a busca de parâmetros podem e devem considerar e aproveitar a variedade e a ligação da educação popular com a EJA, pois esta ainda que de maneira esparsa, buscou de forma específica unir a educação de pessoas adultas à preocupação do sujeito na esfera local e global. A união da sistemática formal com a preocupação 
trazida na vocação da educação popular parece um tanto desafiadora e propositiva transpondo-se como uma das possibilidades de leitura da educação popular. Sobre esse pensamento, Arroyo nos diz:

O diálogo entre o sistema escolar e a EJA será possível e mutuamente respeitoso. (p. 46)

Sobre esse diálogo, o destaque do autor é para a elaboração de alternativas corajosas considerando que "as formas da educação pública não são estáticas, podem e devem ser reinventadas". E como todo processo construtivo e constituinte de uma democracia, a riqueza do processo não beneficiaria somente a EJA, mas o próprio sistema que ao se interrogar, ao se flexionar, se tornaria mais eficaz na aproximação dos sujeitos e no cumprimento de sua função principal: a garantia do direito à educação.

Ainda segundo Arroyo (2005), a história da EJA nos mostra várias tentativas de sair dessa rigidez como única forma de articular as trajetórias de vida e as trajetórias escolares dos setores populares. Nesse sentido, os profissionais de educação empenhados na melhoria do processo formativo podem se valer dos princípios epistemológicos da educação popular e assumir assim, uma postura investigativa a respeito da história da EJA e da história dos sujeitos, tornando-se educadores muito mais ativos ao repensar e ultrapassar as proposições curriculares que se mostrarem demasiado distantes das dinâmicas em sala.

De posse de uma interpretação ampla da educação popular e sua contribuição para a EJA, de como se tornou uma modalidade do sistema escolar e de como é desenvolvida em grande parte sob os moldes de faixas etárias mais novas, é possível pensar experiências no seio do espaço institucionalizado articulando com os fundamentos e contribuições deixadas pela força popular na educação de adultos, jovens e idosos? O que seria necessário para se realizar experimentações nesse sentido? Vejamos no próximo capítulo o relato da experiência realizada pelo Grupo de Ensino pesquisa e extensão em estudos culturais e filosóficos da universidade de Brasília GENPEX /UnB e a análise do corpo docente da Escola de Adultos (escola pública vinculada a Secretaria de Educação do DF) a respeito da reconfiguração desenvolvida nos períodos de 2015 a 2017.

3 - A proposta desenvolvida pelo GENPEX/UnB na Escola de Adultos do Paranoá: a experimentação que germina uma reconfiguração 
Este capítulo retoma o objetivo específico de contextualizar o processo de implantação da proposta de educação popular em uma escola pública que oferta EJA na cidade do Paranoá.

Pode-se dizer que a educação popular se confunde com a trajetória da educação de jovens e adultos e, após a organização no seio da escola regular, este espaço afirmou o direito legal desses grupos ao se tornar a fonte primária de escolarização, mas em contrapartida, devido à estrutura tradicional, pode afastar por vezes o caráter flexível, sócio-político, e outras contribuições que a educação popular semeou ao caminhar com esses mesmos grupos que atualmente compõem a EJA. Para Giovanetti (2005), duas marcas identitárias estão presentes na EJA:

\begin{abstract}
A origem social dos educandos e a concepção de educação que norteia grande parte dos programas, projetos, ações de EJA, uma concepção que, absorvendo o legado da educação popular explicita sua intencionalidade: educação - um processo de formação humana que visa contribuir para o processo de mudança social (p. 244).
\end{abstract}

Na mesma linha, ao tentar compreender as especificidades da EJA, Soares e Soares (2014), ao analisar três projetos de extensão realizados no Brasil (o Projeto Escola Zé Peão, na Paraíba; o Projeto Paranoá, no Distrito Federal; e o Projeto de Ensino Fundamental $2^{\circ}$ segmento, em Minas Gerais, escolhidos conforme o tempo de existência de cada um deles, sua tradição, história e o impacto que têm na comunidade), identificaram seis aspectos essenciais para a elaboração de uma proposta específica para a EJA:

O legado da educação popular, a diversidade dos educandos, a proposta curricular da EJA, os recursos didáticos, a formação de educadores, e as políticas públicas. (2014, p. 17)

Para os autores o legado da educação popular é o que "valoriza e reconhece o saber do aluno através de uma postura dialógica de escuta, que defende a educação libertadora e emancipatória tendo em vista que ela é um direito de todos.” (2014, p.17). Afastar este legado do espaço atual que é responsável por acolher esses estudantes, é quase que negar a história da EJA, os anseios e características desse grupo, é negar a politização, a emancipação, a inclusão social de um povo que tem por direito uma aprendizagem de qualidade e não apenas por terem "perdido tempo, ou fracassado", mas 
principalmente por serem sujeitos aprendizes inclusive na terceira idade, uma sociedade amadurecida e envelhecida também produz, também aprende.

Assim, delinea-se um desafio que compreende de um lado as políticas públicas, e de outro, as práticas pedagógicas que necessitam flexibilizar-se no sistema institucional para otimizar o tempo destinado à conclusão das etapas, considerando a faixa de geração, o mundo do trabalho, as experiências de vida, a condição de não criança e todos os efeitos que a não escolarização anterior ocasionou no aspecto cognitivo e social.

Tais contribuições e especificidades dos projetos, relatadas na pesquisa de Soares e Soares (2014), são marcas fortes e afirmam a permanência e o sucesso até a atualidade. Ainda segundo Soares e Pedrosa (idem), isso se deve ao fato de que:

\begin{abstract}
(...) essas especificidades, presentes nos projetos, influenciam de maneira positiva o aprendizado, a permanência, o sucesso escolar e a melhora da autoestima dos educandos atendidos por estes projetos. Ressaltamos ainda a vitalidade dos projetos estudados, pois, dado a descontinuidade das políticas públicas brasileiras voltadas para a EJA estes projetos permanecem até hoje porque são experiências de referência para pensar o fazer na EJA, e porque atentam para suas peculiaridades. (p.17-18)
\end{abstract}

As experiências em questão, e outras realizadas no Brasil, podem dialogar com as secretarias de educação que ofertam a modalidade de EJA no sentido de qualificar e compartilhar com o processo de educação desses sujeitos, mesmo que disciplinados em um tempo previsto e conteúdos delimitados, a exemplo da proposta do Projeto Paranoá que é discutida neste trabalho.

O Projeto Paranoá, permanece desde a década de 1980 na região administrativa do Paranoá, no Distrito Federal. A motivação desta parceria deu-se a partir da luta dos moradores da anterior Vila Paranoá que lutavam pela fixação, reconhecimento e melhoria da sobrevivência durante e após o período da construção da capital. A parceria inicialmente com o chamado grupo pró-moradia (que em 1987 torna-se CEDEP, Centro de Desenvolvimento e Cultura do Paranoá e permanece até hoje) com o GAJA - Grupo de Alfabetização de Jovens e Adultos, formado pelo movimento popular da cidade, e Universidade de Brasília por meio do Grupo de Pesquisa - GENPEX, visava promover a alfabetização de adultos da própria comunidade. As aulas compreendem a etapa de alfabetização e pós-alfabetização além de oferecer capacitação a professores que desejavam colaborar no projeto. Como forma de organização, são 
realizados encontros de orientação iniciais além dos fóruns semanais (todas as sextasfeiras) de discussão e organização, onde a UnB ainda participa construindo proposições de formação teórico-práticas sobre a ação que a parceria ali desenvolve.

Com registro no Conselho Nacional de Desenvolvimento Tecnológico e Científico ( $\mathrm{CnPq}$ ) desde 2000, em sua composição o GENPEX agrega estudantes de graduação em Pedagogia que atuam por meio dos projetos 4 fases 1 e 2, mestrado e doutorado em educação, professores e servidores da Secretaria de Educação do DF, e outros membros pesquisadores da Universidade de Brasília e outras instituições de nível superior. Anteriormente o grupo era coordenado pelo professor Dr. Renato Hilário dos Reis (1989 até 2016) e atualmente é coordenado pela Professora da UnB, Dra. Maria Clarisse Vieira.

A atuação do grupo de pesquisa é por meio da pesquisa-ação com foco na perspectiva política/pedagógica/histórico/cultural e entende a práxis educativa como sendo fundamental para a construção de um processo educativo real concreto e significante para a formação de um sujeito de amor, poder e saber (VIEIRA; REIS e SOBRAL; 2015, p. 15).

Quantos aos objetivos o GENPEX pretende:

1- Inter-relacionar dialógica e dialeticamente os interesses da Universidade de Brasília (ensino-pesquisa-extensão) e dos migrantes moradores do Distrito Federal;

2- Contribuir com um processo educativo que simultaneamente escolarize e desenvolva a mobilização e organização das camadas populares, por maiores e melhores condições de vida;

3- Aprimorar, ampliar e consolidar as iniciativas de educação popular, iniciada em 1986 com o movimento popular da cidade Paranoá.

4- Desenvolver permanentemente ação-reflexão-ação, com registro, sistematização, produção, e socialização de conhecimento;

5- Apoiar as iniciativas da UnB e de outras instituições públicas na área de educação popular de crianças, adolescentes, jovens, adultos e idosos (VIEIRA, SOBRAL, REIS, 2015).

As atividades desenvolvidas pelo GENPEX na Escola de Adultos e no CEDEP, seguem os eixos pautados em princípios da educação popular. A preocupação com a 
permanência dos estudantes na escola e com a continuidade dos estudos surge com o possível estranhamento que os estudantes que vivenciaram essa abordagem educativa poderiam ter ao vivenciar a prática educativa tradicional existente nas classes de EJA.

São eixos fundantes da práxis:

1-Amorosidade/acolhimento: Na educação infantil, a afetividade é traço forte para o bom desenvolvimento das sinapses neuronais e do aspecto sócio-afetivo da criança. Na educação de adultos há também que se ter uma afetividade, dita numa abordagem específica como amorosidade/acolhimento pois, apesar de já se ter uma ideia de mundo e experiência bem construídas, o processo de desenvolvimento não está completo. Outro motivo deste eixo é que o público da EJA carrega em si um pensamento inferior, de que "nada sei, "nada sou", "analfabeto não é ninguém". A autoestima, que se relaciona diretamente com o processo de aprendizagem, é ferida pela exclusão social, política, econômica e histórica vivenciadas pelas desigualdades do país. Este eixo tem como foco o dessilenciamento, "destramelamento da pessoa" ((VIEIRA; REIS e SOBRAL 2015, p.16). Trata-se de propiciar gradativamente e dialogicamente uma abertura do "eu" e do "outro". Essa abertura é fundamental para a permanência e para o desenvolvimento integral do sujeito que retorna à escola com medos, anseios e preconceitos pela "idade avançada" e pelo "tempo perdido".

2 - Situação-problema-desafio: No processo de aprendizagem e desenvolvimento integral do sujeito dentro da perspectiva histórico-crítica de educação, é necessário que se desenvolva a autoconsciência e a consciência do todo em que o sujeito se encontre. A percepção e capacidade de diagnóstico, diálogo, construção coletiva e resolução de desafios são práticas indispensáveis para a aprendizagem e a escola é palco principal desta prática. A situação-problema promove a desnaturalização do problema que está presente, desvela os motivos da existência e estimula o pensamento crítico dos sujeitos. Cada grupo possui uma situação-problema-desafio, por vezes oculta, mas que com o processo de discussão e indagações, a situação se delimita, e é no processo de discussão, defesa de posição, votação com a maioria simples ou absoluta que é eleita uma situação para que esta seja a espinha dorsal que irá ramificar com a Língua Portuguesa, Ciência, Linguagem matemática, linguagem informática, artística, e outras que forem necessárias ((VIEIRA; REIS e SOBRAL, 2015, p. 20). 
3 - Texto coletivo: Considerando que a fala está diretamente ligada ao processo de escrita, o que se fala vira texto, vira símbolo. Ao desenvolver a prática herdada de Paulo Freire, o texto coletivo integra três aspectos: oralidade, escrita e construção coletiva. O texto coletivo transcreve a palavra falada, registra as ideias construídas e expressa uma autoria coletiva visando sempre o pensamento de coletividade, de compartilhamento através de palavras vindas de dentro, de dentro da realidade e contexto imediato dos educandos, é uma das ações que propiciam o empoderamento e resgate da autoestima, segurança, confiança que irão se perpetuar em vários segmentos em que os educandos estiverem presentes e tiverem que agir/pensar.

4 - Fórum: o fórum é uma espécie de reunião-assembleia que engloba os membros do movimento popular, os educandos e alfabetizadores, professores e estudantes da UNB. Em cada fórum, cada grupo exercita e realiza a exposição e argumentação de uma situação-problema. É livre o debate e a contra-argumentação. Após a votação $(50 \%+1)$ elege-se uma situação que norteará o processo de alfabetização por um bimestre, trimestre ou semestre. Assim, é votado também as formas de encaminhamento e superação da situação com reuniões de acompanhamento e compartilhamento das produções textuais e imagéticas desenvolvidas ao longo do período. Trata-se de mais um instrumento de debate, exercício de escuta e fala, temas imediatos nas discussões que são úteis ao cotidiano de adultos e idosos. Importante destacar que o GENPEX também realiza semanalmente reuniões de planejamento para as atividades que serão realizadas na escola.

Outra abordagem utilizada no início de todo semestre (na escola) é a autoapresentação e conhecimento pelo nome próprio, com a intencionalidade de visibilização e valorização da individualidade e protagonismo de cada um (SOBRAL e REIS, 2017).

Em 2015, surgiu entre os membros do projeto, uma preocupação quanto à continuidade dos estudos dos educandos que ali iniciavam o processo de alfabetização. Havia todo um processo de busca e cativo destas pessoas na comunidade para que frequentassem o espaço na busca por uma educação emancipatória. E por esta preocupação, neste momento, o GENPEX consegue uma parceria com a Coordenação Regional de Ensino do Paranoá por meio da Escola de Adultos que aceita a entrada do GENPEX na escola, participando de forma direta na formação dos educandos que vem do projeto, do programa DF ALFABETIZADO, e todos os outros. 
Com todos esses objetivos e eixos, o GENPEX desde 2015 até 2017 completa dois anos de atuação na Escola de Adultos e passa por reconfigurações que caminham para a permanência e afirmação da possibilidade de união entre a educação de jovens e adultos institucionalizada e os fundamentos da educação popular.

Configuração inicial (2015 a 2016): Quando o GENPEX inicia a inserção e o conhecimento da escola em 2015, o curso de Ciências da Computação da UnB, já desenvolvia um projeto de noções básicas de computação e inclusão digital para a EJA. As atividades foram desenvolvidas inicialmente no mesmo espaço e tempo que este grupo de graduandos do curso de Ciências da Computação, mas com enfoques distintos.

O GENPEX possuía enfoque de formação centralizada no sujeito, o grupo de Ciencias da computação, com enfoque mais técnico e instrumental. Posteriormente, o grupo de Ciências da computação se retira e o GENPEX permanece aprofundando os trabalhos iniciados com as turmas, a equipe pedagógica, e aperfeiçoando o trabalho.

Um exemplo deste enfoque é quando o GENPEX realiza um questionário para conhecer o público das turmas e traça a partir do ideal de valorização da identidade cultural, uma proposta de se trabalhar receitas culinárias regionais, tema sugerido por uma das docentes. O desenrolar desta atividade foi permeada pela valorização das vozes de cada sujeito no processo de escolha da receita de cada turma, pela investigação dos sentidos e significados dos ingredientes, das origens e das diferenças de cada receita. Toda a discussão e exercícios relativos a esta temática resultou num livro de receitas. Tal proposta se diferenciava da exploração técnica usual do computador como ferramenta, mas não excluía a inclusão digital durante as aulas.

Importante destacar que a composição do GENPEX também era e ainda é formada por graduandos, matriculados em estágio supervisionado (Projeto 4 fases $1 \mathrm{e}$ 2), e estudantes de mestrado e doutorado, o que contribui diretamente para a formação de professores e para experiências quanto à realidade da EJA escolar. Aparece então, um novo desafio: como desenvolver a práxis de educação popular, utilizando o laboratório de informática?

Em termos quantitativos, no segundo semestre de 2015, o projeto atendeu 5 turmas de $1^{\mathrm{a}}$ a $4^{\mathrm{a}}$ etapa, durante à noite, três dias da semana, de 19h às 21:20. Segundo Sobral e Reis (2017), foram atendidos 100 alunos e alunas neste momento.

No tocante à relação com o corpo docente da escola, objeto que circunda este trabalho, pode-se afirmar que era uma relação praticamente inexistente. Os professores 
sabiam que havia o projeto mas não acompanhavam de perto as turmas durante as aulas. As temáticas desenvolvidas no laboratório não caminhavam junto ao que o professor desenvolvia diariamente na sala. O que acontecia em termos de interação eram sugestões por parte de uma professora de temas para o semestre. Era uma relação independente em grande parte, não havia diálogo. Posteriormente, o grupo da Ciências da Computação se retira e apenas o GENPEX continua o projeto.

Configuração atual: Ao longo de 2016, outras temáticas foram desenvolvidas e a aproximação com os docentes continuava da mesma forma: um ou outro sugeria temas e apenas isto. A partir do primeiro semestre de 2017, os esforços em agregar os professores na proposta dialógica e fundamentada na educação popular começaram a se efetivar e tiveram grandes avanços mas ainda está em construção. Os docentes das turmas passaram a acompanhar o GENPEX no laboratório de informática e o GENPEX a participar da aula realizada por eles no horário seguinte, sendo cada dia em uma turma diferente. Ou seja, a atuação agora acontece em dois espaços. Os horários permanecem e a quantidade de dias também, agora atendendo 4 turmas. Assim é a nova configuração:

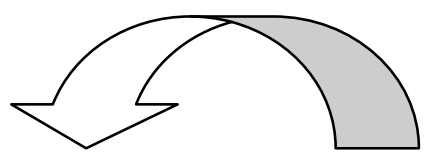

$1^{\circ}$ horário:

Quem: Metade dos integrantes do GENPEX (matriculados em estágio supervisionado) + metade dos educandos.

Onde: Sala de aula $1^{\circ}$ horário:

Quem: Metade dos integrantes do GENPEX (matriculados em estágio supervisionado) +docente da turma + metade dos educandos.

Onde: Laboratório de informática

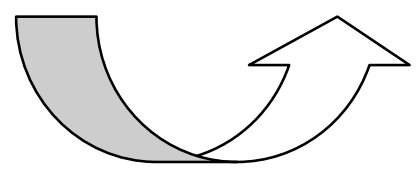

No segundo horário os grupos de educandos se alternam. 
Esta nova configuração permitiu a imersão e envolvimento dos docentes na proposta, uma vez que o mesmo disponibiliza sua sala de aula para atuação dos estudantes em formação na UnB.

A partir do primeiro semestre de 2017, o quadro de professores foi renovado com a contração temporária de novos professores e a relação com os docentes aparece mais aberta ao diálogo. Um novo braço fundamental é fortalecido. Quanto à presença nos espaços do projeto, os docentes já estão aliados e dispostos, mas o planejamento é que se apresenta como desafio pela falta de tempo dos professores por realizarem outras tarefas que demandam maior tempo. Dessa forma, a alternativa encontrada diante da necessidade do diálogo foi de planejar no ato. É na dinamicidade do momento que surgem ideias e proposições. Estas vão sendo registradas por integrantes do grupo, além de conversas em rede social que servem de suporte para idealização de projetos e atividades. É durante o decorrer da aula e ao observar a turma que o planejamento se inicia. O planejamento é aprofundado tendo como base as discussão nas reuniões semanais do grupo na UnB, o registro e a reflexão sobre as dificuldades dos estudantes, as facilidades, as temáticas de interesse, os perfis mais retraídos, os mais desinibidos, o tipo de atividade desenvolvida, o tempo necessário e os próximos conteúdos que irão se encaixar. Nestas reuniões são discutidas estas impressões das aulas e consideradas as proposições e ideias dos professores, desta forma, elabora-se um plano de aula com vocação popular.

A partir de 2015 até 2017 algumas temáticas semestrais sustentaram o processo de alfabetização. Em resumo foram desenvolvidas as seguintes atividades:

A) Histórias de vida: Proposta que visou reconstruir as origens destes sujeitos a partir da escrita de suas histórias e trajetórias;

B) Livro de receitas: Proposta que visou identificar elementos do cotidiano dos estudantes por meio da valorização culinária;

C) A escola que temos e a escola que queremos: Proposta que visou explorar e analisar criticamente o ambiente em que estudam na perspectiva da superação de problemas;

D) Cultura e museus: Proposta de visou à integração cultural e reconhecimento dos estudantes com museus a partir de saídas de campo; 
A temática de 2017 contou com a participação docente nos moldes do que foi descrito acima. Cada atividade conta com a sistematização e registro nos arquivos do Grupo de pesquisa.

Inicialmente o desafio de se trabalhar com a ferramenta digital foi para o grupo um ponto de questionamento e avaliação: como fazer? E como ter os docentes trabalhando conosco?

Partindo da concepção de que o Programa Nacional de Tecnologia educacional - PROINFO, se destina ao uso pedagógico (MEC, 2007) das ferramentas tecnológicas, o uso meramente técnico não é tão focalizado com a implementação de laboratórios no interior das escolas de educação básica. O grupo do GENPEX apesar de não ter formação específica na área tecnológica, tem conhecimentos na área pedagógica, o que pressupõe ideias e inovações na forma de trabalho. Com as discussões e contribuições dos membros do GENPEX, o grupo conseguiu desenvolver atividades pedagógicas sem se afastar da proposta de educação popular promovendo simultaneamente à inclusão tecnológica e a experimentação direta com funções diversas do computador.

A instalação de um laboratório de informática não deve excetuar os conhecimentos da sala de aula e sim tornar os dois espaços em uma forma integrada de aprendizagem. A presença de monitores ou agentes especializados em informática não pode inibir a participação docente no processo. Toda e qualquer ação que seja desenvolvida neste espaço assim como em outros na escola, deve fazer parte de todo o planejamento político pedagógico da instituição.

Nesse sentido, como parte da contínua aproximação com o corpo docente da escola, se torna necessário ouvir a análise deste grupo quanto a realização do projeto para compreender o impacto da ação desenvolvida em sua rotina pedagógica.

Com as modificações ocorridas na rotina escolar, podemos afirmar que há uma germinação de uma nova configuração para o modelo de EJA nesta escola. A avaliação do corpo docente é peça e componente primordial para a reflexão dos moldes que o projeto caminha e caminhará, trazendo assim considerações ou reformulações para o aperfeiçoamento da relação universidade e escola, EJA e educação popular.

\section{1 - A análise do corpo docente quanto à prática pedagógica desenvolvida pelo GENPEX: análises, significações e ressignificações do processo}


Neste subcapítulo, são retomados dois objetivos específicos: Analisar como foi/é a participação docente neste processo de inserção da educação popular na EJA e analisar as significações atribuídas deste processo de inserção pelo corpo docente da escola.

Com base no corpus produzido na pesquisa e a partir das entrevistas, da leitura e releitura exaustiva do material das entrevistas, foi possível elaborar três categorias para análise, entre as quais:

\begin{tabular}{|c|c|c|c|c|c|}
\hline 1 & $\begin{array}{l}\text { PERFIL DO DOCENTE } \\
\text { COM RELAÇÃ̃ } \hat{A} \\
\text { EJA }\end{array}$ & 2 & $\begin{array}{l}\text { PERFIL DO DOCENTE COM } \\
\text { RELAÇÃO À EDUCAÇÃO } \\
\text { POPULAR: }\end{array}$ & 3 & $\begin{array}{l}\text { AVALIAÇÃO DOCENTE DA AÇÃO } \\
\text { DO GENPEX: }\end{array}$ \\
\hline & $\begin{array}{l}\text { DIMENSÃO } \\
\text { CRÍTICA; }\end{array}$ & & $\begin{array}{l}\text { DIMENSÃO FORMATIVA } \\
\text { EXPERENCIATIVA; }\end{array}$ & & $\begin{array}{ll}\text { a) } & \text { DIMENSÃO } \\
& \text { TRANSFORMADORA: } \\
& \\
\text { - } & \text { QUANTO ÀS } \\
& \text { TRANSFORMAÇÕES DO } \\
& \text { DOCENTE INTERNAS } \\
\text { - } & \text { QUANTO AS } \\
& \text { TRANSFORMAÇÕES } \\
& \text { PERCEBIDAS NOS DISCENTES } \\
& \text { (EXTERNAS) }\end{array}$ \\
\hline
\end{tabular}

Quanto ao perfil geral de formação profissional dos docentes entrevistados (duas mulheres e dois homens), podemos fazer as seguintes considerações: todos possuem nível superior em Pedagogia ou e em outras áreas de conhecimento:

D1: Psicologia, matemática, Ciências contábeis, Pedagogia e atualmente faço mestrado em Educação (...)

D2: Sou formada em Pedagogia e tenho uma especialização na área de orientação e supervisão pedagógica.

D3: Eu fiz graduação em Sistemas da informação e complementação pedagógica e matemática (...) Depois senti vontade de fazer Pedagogia e fiz (...) Fiz especialização em EJA pela UnB também. .

D4: Sou formada sim, em Pedagogia.

Os quatro docentes atuam nesta escola em quatro etapas das séries iniciais da Educação de Jovens e adultos e lecionam a disciplina de Português ou Matemática, um deles é coordenador. A atuação com a educação de jovens e adultos é recente, sendo três deles regidos por contrato temporário, um por contrato efetivo. Esta é uma questão de destaque, pois a maioria dos professores do período noturno é de contrato temporário, o que pode conferir uma provisoriedade e fragilidade na relação com os educandos. A 
transitoriedade deste aspecto pode afetar no processo de identificação do docente com o público noturno e vice versa, visto que é algo temporário, e o impacto no envolvimento e atuação do docente pode vir a ser limitado pelo mesmo motivo.

\begin{tabular}{|l|l|}
\hline $\begin{array}{l}\text { D1: } 1 \text { ano de atuação na EJA (12 anos de contrato } \\
\text { temporário) }\end{array}$ & D2: 1 ano de atuação na Eja (Contrato temporário) \\
\hline $\begin{array}{l}\text { D3: } 9 \text { anos de atuação na EJA (sendo o único com } \\
\text { contrato efetivo) }\end{array}$ & $\begin{array}{l}\text { D4: } 9 \text { meses de atuação na EJA (Contrato } \\
\text { temporário) }\end{array}$ \\
\hline
\end{tabular}

Além de possuir contrato temporário na SEDF, os docentes também possuem experiência com outras etapas de ensino acumulando jornadas duplas de trabalho, outro fator que pode interferir diretamente na qualidade do trabalho pedagógico:

D1: Eu trabalho no sistema S, trabalho nas escolas do SESI de dia,mas aqui to temporário. No EJA oficialmente, oficialmente, esse é meu primeiro ano (...) Também já trabalhei com socioeducação (...)

D2: Lá em Água lindas dou aula pra ensino fundamental de dia... primeiro fiquei 3 anos com a educação infantil e nesse ano to dando aula para o segundo ano, to trabalhando 60hs semanais.

D4: Efetiva na educação infantil há 3 anos, no período diurno. E na EJA contrato temporário, 60 horas.

\subsubsection{PERFIL DO DOCENTE COM RELAÇÃO À EJA: DIMENSÃO CRÍTICA}

Muitos elementos foram evidenciados quando os docentes começaram a refletir o que para eles seria a EJA. A consciência da transformação que a educação escolar pode trazer à vida destes estudantes, o incentivo, a oportunidade, o desafio, a busca, o interesse, a significação e a visão compensatória, foram impressões e ideias marcantes muito abordadas neste trecho. Todos os docentes apresentaram sensibilidade quanto às características deste grupo e se demonstraram a disposição para aperfeiçoar suas práticas e melhorar a qualidade das aulas, ainda que com as dificuldades existentes. Com relação à visão dos docentes para a Educação de Jovens e adultos, foi perguntado inicialmente:

P: Para você o que é a educação de jovens e adultos? Conte-me um pouco sobre sua experiência na eja? (aspectos que a levaram a se inserir nessa área): 
E os depoimentos foram:

D1 - (....) A EJA é diferente. Ali, eles estão ávidos pelo conhecimento, eles querem aprender. Eles querem desenvolver, eles querem mudar a realidade deles, então ai você começa cada vez mais, você quer buscar cada vez mais uma aula participativa, você quer passar pra eles tudo que você sabe, você quer mostrar pra eles, como que é a vida, você quer ensinar em todos os aspectos né, apesar da idade deles, mas eles querem e isso é bom demais (...)

Bom, a EJA pra mim literalmente é você dar oportunidade pra aqueles que não tiveram nem chance de concluir na época correta, né. Então eu acho que EJA é isso, mas é muito mais na realidade. EJA pra mim é também você trazer a realidade, trazer as coisas, os acontecimentos, (...) Então eu entendo a EJA como desafio, você realmente fazer alguma coisa pra modificar a realidade do aluno, e você ver o aluno e ficar muito feliz do aluno dizer assim: Professor, eu já consigo não pegar mais ônibus errado!

D3: A EJA para mim tem o sentido de resgatar e retomar o tempo perdido.

D2: é uma oportunidade, uma descoberta, pra eles é algo muito valioso (...) Acho que pra essas comunidades que não tiveram chance de estudar, nunca é tarde, e a EJA ajuda bastante. (...) Ontem estive incentivando uma estudante que reclama muito do trabalho pesado, diz que sente muitas dores, e falei pra ela: menina, estuda mais pra ver se você consegue um emprego mais tranquilo...

D4: É a educação ofertada àqueles que por diversos motivos não puderam concluir seus estudos no tempo ideal. Comecei este ano no CEF 01 em uma turma de terceira série, porém logo chegou uma professora efetiva. Depois de um mês fui chamada para a EC 03, é maravilhoso e desafiante o trabalho com alunos da EJA.

Ao analisar os trechos grifados, um aspecto aparece na fala de todos os docentes: a concepção do "tempo perdido" e da "oportunidade" que a EJA proporciona. Inegavelmente, grande parte do público de EJA não teve acesso á uma educação de qualidade no tempo adequado e hoje tem esse direito afirmado em lei, o que amplia as melhorias prospectivas em suas vidas. Entretanto, essa concepção de que a EJA existe para compensar um tempo perdido, pode influenciar diretamente no desenvolvimento de uma educação acelerada e estanque pelos professores. Nesse sentido, Machado (2016) afirma que a EJA mesmo após 20 anos de advento da Lei de Diretrizes e Bases da educação em 1996, continua reproduzindo "um passado que 
ainda não passou". Segundo a autora, a herança das campanhas rápidas e do supletivo reafirma uma educação aligeirada que visa a certificação para o mercado de trabalho. Arroyo (2005), na mesma linha, também afirma que os jovens e adultos continuam percebidos na ótica da carência escolar e que esse olhar precisa mudar de uma ideia de segunda oportunidade, para uma ideia de direito à educação. A permanência dessa visão de resgate do tempo perdido precisa de uma atenção:

A EJA somente será configurada se esse olhar for revisto (...) Um novo olhar deverá ser construído, que os reconheça como jovens, adultos e idosos em tempos e percursos de jovens e adultos. (p. 23)

Se for afirmado um caráter apenas de compensação, como uma forma de certificação rápida e segunda chance, pode-se precarizar o direito à qualidade do processo, assim como o reconhecimento da capacidade de aprendizagem contínua.

Quanto ao aspecto transformador, os docentes sabem que a sociedade está em constante mudança e conhecem a realidade dos grupos que compõem a EJA. Apresentam em suas falas a necessidade de uma educação transformadora para a vida dos sujeitos. Os docentes sinalizaram essa necessidade apesar da lógica compensatória. Simultaneamente, também está presente na fala dos docentes a necessidade de uma educação comprometida, nos moldes do que Giovanetti (2005) afirma ser necessário para a formação de educadores em EJA:

Ao abrir-se para os sinais de alerta construídos pela educação popular, no tocante à realidade da exclusão social, a EJA assume um caráter de uma educação compromissada em reverter o quadro muitas vezes já naturalizado, das desigualdades sociais (p. 245)

A visão de um tempo perdido, de algo que falta, também aparece e segundo a autora (idem) é necessário reeducar esse olhar para superar a negatividade:

Ao reeducar o nosso olhar docente, à luz do legado da educação popular, poderemos superar a negatividade ainda tão presente em nossas abordagens sobre os alunos de EJA, ainda referidos por meio de uma visão marcada pela "carência", o que acaba por reafirmar uma postura preconceituosa e estigmatizada. (p. 247).

Um dos pressupostos para o educador de EJA e para a construção do trabalho pedagógico flexível é a consciência de suas marcas identitárias. Giovanetti (2005) nos 
diz ser: a composição social e o legado de uma educação popular. Portanto, no tocante à dimensão crítica, os docentes analisados parecem atender a esse pressuposto, apresentam uma concepção de transformação social que a EJA possui e tem consciência dos desafios iniciais de suas práticas.

\subsubsection{PERFIL DO DOCENTE COM RELAÇÃO À EDUCAÇÃO POPULAR: DIMENSÃO FORMATIVA EXPERENCIATIVA}

Grande parte dos estudantes que frequentam a Escola de Adultos iniciaram o processo de alfabetização no Projeto Paranoá realizado pelo Cedep/GENPEXUnB/Movimento popular ou no DF Alfabetizado. A ação do movimento popular na cidade é histórica e constante e revela uma preocupação com a permanência e a continuidade do processo de aprendizagem desses estudantes após se matricularem nas escolas. Por este motivo, a parceria com o GENPEX visa qualificar o processo levando contribuições da educação popular para as práticas desenvolvidas no interior da escola, que por vezes são tradicionais e compensatórias, visando certificação acelerada.

A ação docente não se limita somente ao ensinar conteúdos curriculares, e não atinge somente os limites de uma sala de aula. Ao imergir-se numa sala de aula, o docente também está vivendo e transformando aquela comunidade, pois tem experiência direta com seus habitantes, o poder de influência é considerável. É necessário conhecer a comunidade, para traçar a rota de ação político-pedagógica que desenvolverá em equipe naquela escola.

Visto que nessa comunidade a atuação do movimento popular é latente, histórica e ainda luta pela sua existência e pela emancipação do povo naquela região, é importante que os docentes tenham conhecimento e apropriação disto, é importante que conheçam seu local de trabalho-ação. O domínio do conteúdo para o povo não é suficiente, é necessário saber, o que saber, como fazer, e como desenvolver, e essa é a perspectiva que o movimento popular preza nas mais diversas parcerias que firmam.

Nesse sentido, na tentativa de saber se existem conceitos e experiências de educação/movimento popular relacionados na trajetória destes docentes, foi perguntado: 
1- $\quad$ Para você o que é a educação popular?
$1.2 \quad$ Você tem experiência nessa área?

D1: Bom, Agora que eu tô aprendendo muito. Eu não tinha muita noção. Conheço o movimento do Paranoá porque eu acompanhei no jornal da época, a ocupação, a doação de lotes, a briga toda, tudo, acompanhei pelos jornais. Era a época que eu tava na UnB, não acompanhei o projeto mas ouvi falar que o pessoal tava ajudando aqui, mas não participei porque na época eu já trabalhava e estudava.

D2: Não eu nem conhecia, tô descobrindo agora esse ano através do CEDEP, eu achei super legal, nunca tinha tido essa experiência. Lá no Rio também nunca vivenciei, sempre trabalhei em escolhinha particular pequenininha. Agora aqui com o EJA que to conhecendo o CEDEP, e aí que vim conhecer. Mas assim, é outra realidade quem trabalha em escola particular, escolhinha pequena. Não tem essa realidade de lutas e causas, é outra coisa....minha vida era uma vidinha mais pacata, escola, faculdade, casa, e vai e volta, né... Não tinha essa visão aberta, dessa importância da militância. E, eu acho que educação popular abrange todos que não tiveram acesso, abrange aquelas pessoas que tem especificidades, que precisam de um olhar diferenciado, educação popular pra mim é isso. É ver aquela população que não teve acesso, que não teve oportunidade e você abrir uma educação de qualidade.

D3: Não. Nunca tive nada, fiz uma pós na EJA na UnB, mas com movimento e educação popular nunca tive nenhuma experiência.

D4: Não, nunca participei de movimento popular. Mas acho que é a educação que busca conhecer o estudante, valorizando sua cultura, o meio em que vive para a partir daí produzir o plano de ação.

Com relação à formação e experiências com movimento ou educação popular, ficou evidenciado que os docentes não possuem experiência alguma. Um dos docentes relata que até poderia ter participado do movimento popular do Paranoá na época de 80/90, mas por ter pai militar, foi alertado também a não se envolver. Os principais fatores que limitaram o envolvimento com as práticas populares dos docentes foram: tempo, rotina, trabalho. Apesar de não haver experiência ou formação específica quanto à educação/movimentos populares, alguns docentes afirmaram que estão conhecendo agora - após adentrarem o espaço da EJA e realizarem, curso de formação desenvolvido pela UnB - o que é educação popular e qual a relevância dela para a EJA (ver grifos acima).

A Educação de Jovens e Adultos ensina. Visto que não há uma formação específica para atuar em EJA, os docentes não tiveram formação específica para avaliar a inserção da educação popular no campo da EJA institucionalizada, mas afirmam claramente as especificidades dela e o tratamento efetivo com os sujeitos. As análises 
deles vão ao encontro dos pressupostos da educação popular embora não utilizem o termo educação popular em seus depoimentos. Não obstante, não possuírem formação teórica, os docentes demonstraram um saber constituído e legitimado em seus fazeres e vivências docentes. Ficou visível a relação inseparável da educação popular com a EJA e a capacidade de ditar aos espaços, a flexibilidade dessa modalidade, e foi a partir dessa autodeclaração da EJA que eles legitimaram seus saberes demonstrados na entrevista. A Educação de Adultos revela neste trabalho seu caráter autodeclaratório: ela mesma transfigura suas especificidades e o professor constrói o saber com base nas vivências da rotina pedagógica. No trecho abaixo um dos docentes relata sobre a dificuldade de material para se trabalhar com adultos e idosos e que precisou da experiência, de viver a turma, para então começar a abordagem educativa:

P: Quando você chegou a primeira vez na EJA, o que você sentiu nesse momento em relação aos materiais e abordagens? Você teve alguma dificuldade?

D2: Senti perdida. Não sabia como... é... chegar neles, como iniciar uma aula com eles, não sabia aí fui pesquisar na internet olhar várias, coisas, falar com outros colegas, aí fui interagindo com eles, sentindo, buscando, vendo o que eles precisavam, o que eles necessitavam, o que eles tinham mais dificuldade e nisso eu fui trabalhando pra depois eu entrar no currículo de fato. Não adiantava eu entrar com o currículo sem conhecê-los, sem saber o que eles precisavam o que eles queriam e eu fui casando e ta dando certo. Avalio de forma positiva essa experiência de sentir a sala. Muitos alunos chegaram pra mim e não conseguiam ler, hoje estão lendo naturalmente.

Outro trecho em que a docente afirma a necessidade da flexibilidade e da dialogicidade - bases epistemológicas da educação popular - é quando ele comenta sobre a rotina dos estudantes e de como isto interfere em sala de aula:

D2: Eles têm um trabalho pesado... A gente sempre tem que tá incentivando, o dia é muito, muito pesado, muitos querem desistir, de noite ainda vir pra cá. Não é fácil. E nossa função. Não é só chegar lá e dar aula, tem de conversar com eles, ouvir os problemas...

A consideração com a identidade da EJA é fundamental para afirmar as suas especificidades e pensar outros modelos de educação. Para Arroyo (2005), deixar a identidade da EJA de lado é ver a EJA como mera oferta individual de oportunidades pessoais perdidas. Para o autor, as trajetórias destes estudantes não se tornaram mais 
fáceis, o mundo do trabalho é marca no mundo adulto e não é diferente nas classes de EJA, assim, D2 deixa isso muito claro quando acolhe a condição de cansaço durante a aula ocasionada pelo trabalho diário.

Neste momento D4, que estava presente na sala dos professores em um dia diferente de sua entrevista, diz:

D4: Tem dia que na realidade eles não querem nem aula, eles querem apenas que a gente ouça o sofrimento deles, como foi o dia deles, às vezes você planeja uma aula e as coisas vão para outro rumo. Chegam ali com um problema, outro dia chegou aluna reclamando e chorando que o filho dela tava dando problema pra ela, ai sentei do lado, tive que dar abraço e conversar. Ela disse que queria desistir, e todo mundo ali foi dando força incentivando... É uma família, né... Então é sim quase uma família.

D2: E sendo dessa forma acaba surgindo uma maior aprendizagem, se for algo muito rígido, dever, copiar, etc, não tem conversa, aí a aprendizagem não vem porque tá travada.

D4: Sim, às vezes a pessoa chega lá com um problema, ela que expor, ouvir uma palavra amiga e ela encontrando isso dá forças pra ela continuar.

D2: Eles chegam mudos, travados, mas depois se abrem, não trato com amorosidade apenas, mas com amizade. Trocamos whatsapp, escutamos, conversamos, eles se sentem em casa né, já trabalham o dia todo e ir pra uma aula chata né, isso não pode acontecer. Tento fazer com que a aula fique menos pesada, por mais que tentamos fazer uma aula leve, ainda sim fica cansativo.

O trecho destacado demonstra a necessidade de uma educação pautada também na amorosidade, outra base de influência da educação popular, pois o indivíduo não se desvencilha de suas preocupações diárias, ao se matricular numa turma de EJA. Uma abordagem subjetiva de estimular a continuidade dos estudos e entender o contexto de vida, englobando a especificidade, pois existem mais motivos práticos para desistir do que para continuar os estudos. Assim D2 e D4 afirmam a importância do acolhimento para a manutenção da trajetória que lhes é de direito. São vestígios da necessidade da educação popular na fala dos docentes.

Após analisar a dimensão experenciativa de educação popular, pôde-se concluir que os docentes elaboraram um saber quanto ao tratamento que os sujeitos da EJA anseiam com vistas a promover a permanência deles na escola. Saber este, que não conta com apropriação de conceituação teórica específica de educação popular, mas que conta com fundamento prático obtido na experiência com jovens, adultos e idosos. A 
educação popular é viva no contexto da EJA e transcende a conceituação teórica por si só.

A discussão sobre os saberes docentes faz parte de um movimento iniciado nos anos 80 a partir das reformas que visaram a profissionalização do ensino na América do Norte e Latina. Tardif (2002) nos faz pensar sobre quais saberes são realmente necessários para que os profissionais realizem suas atividades e como estes saberes se integram na execução das tarefas, como são aplicados, utilizados e transformados dentro dos limites e recursos disponíveis no trabalho.

Para Tardif:

O saber tem sentido amplo que engloba os conhecimentos, as competências, as habilidades, (ou aptidões) e as atitudes dos docentes, ou seja, aquilo que foi muitas vezes chamado de saber, de saber-fazer e de saber-ser".(2002, p.60)

No exercício docente há uma pluralidade de saberes necessários, não somente o domínio do conteúdo ministrado, mas todo processo construído e vivido após sua formação profissional. No que diz respeito aos saberes dos professores, Tardif (2002) afirma que estes saberes parecem ser plurais, compósitos, heterogêneos, e se manifestar a partir do próprio exercício do trabalho, sendo provenientes de diversas fontes. Um apontamento relevante é quando o autor diz que a experiência é fonte privilegiada do saber-ensinar:

\footnotetext{
Além disso, os saberes não correspondem, ou pelo menos, muito pouco, aos conhecimentos teóricos obtidos na universidade e produzidos pela pesquisa na área de educação: para os professores de profissão, a experiência de trabalho parece ser a fonte privilegiada de seu saber-ensinar.(2002, p.61)
}

Para organizar as espécies de saberes dos professores, o autor elabora um quadro tipológico que tenta dar conta do pluralismo do saber profissional, com cinco tipos de saberes, suas fontes sociais de aquisição e os modos de integração no trabalho docente: 1: Saber pessoal; 2 - Saber proveniente da formação escolar anterior; 3- Saber proveniente da formação profissional para o magistério; 4-Saber proveniente dos programas e livros didáticos usados no trabalho; e por último o quinto saber: Saber proveniente de sua própria experiência na profissão, na sala de aula e na escola. 
Os saberes quanto a pratica com os sujeitos da EJA demonstrada pelos professores participantes do projeto na Escola de Adultos se enquadram na última categoria: saberes provenientes da experiência na profissão, na sala de aula e na própria escola, tendo como fonte a prática do ofício integrado pela socialização que o GENPEX, no exercício da extensão universitária tenta propor de forma gradual e com a realização de atividades dialogadas com cada protagonista do projeto.

Tardif (2002) afirma que "os professores não possuem somente uma única concepção de prática, mas várias concepções em função das realidades cotidianas e biográficas de suas necessidades, recursos e limitações” (p. 65). Considerando esta pluralidade de saberes e a pluralidade da EJA, a reconfiguração que o GENPEX propõe na escola permite ainda a pluralidade de concepções, mas permanece o eixo dorsal da educação popular. É uma relação de troca: os estudantes identificam uma situaçãoproblema, e os conteúdos curriculares permeiam a construção do conhecimento. A estrutura tradicional não é colocada de lado, pois esta também tem suas contribuições à formação do educando. Há que se considerar o contexto para que se possa reconfigurar gradualmente o processo.

O próximo subcapitulo irá discutir a terceira categoria de análise que apareceu nesta avaliação realizada: transformações ocorridas na subjetividade destes docentes ao vivenciar o processo de aproximação da escola com a universidade, estas significações também resultaram no surgimento de outros saberes fundamentados em suas experiências com a EJA e com o GENPEX.

\subsubsection{ANÁLISE DOCENTE DA AÇÃO DO GENPEX}

Com objetivo geral de analisar em que medida a interação entre o modelo formal da EJA e da educação popular contribui para a ressignificação da visão docente acerca da prática pedagógica desenvolvida, foi identificada nesta análise a dimensão transformadora interna e externa. Como transformação, ficou evidente que os docentes estão construindo saberes a partir desta interação dos modelos tendo como fonte a experiência prática com o público de EJA e com o GENPEX. A seguir, o desdobramento desta dimensão: 


\section{A) DIMENSÃO TRANSFORMADORA - QUANTO ÀS TRANSFORMAÇÕES OCORRIDAS NO DOCENTE (INTERNAS)}

As transformações denominadas como internas dizem respeito às modificações ocorridas no comportamento do docente, remetem à própria subjetividade. Ao analisar estas modificações e ressignificações dos docentes, vários saberes fundamentados na percepção e na prática docente se delinearam. Tais saberes reconhecidos vão assertivamente ao encontro à obra de um dos principais precursores da educação popular no Brasil e no mundo, Paulo Freire. A obra Pedagogia da autonomia, saberes necessários à prática educativa (1996), foi utilizada neste capítulo para legitimar os saberes demonstrados pelos docentes neste processo de análise. Chamo atenção para o fato de esses saberes estarem transpostos na fala e na ação dos docentes ainda que não tenham tido apropriação teórica do tema. Para começar, foi realizada a seguinte pergunta:

P: Como o trabalho do GENPEX interfere em sua prática pedagógica? Em seguida expliquei melhor: Como avalia essa nossa entrada aqui na escola?

E os depoimentos foram:

D1: Faço com prazer essa avaliação. O GENPEX pra mim é uma realidade que eu não conhecia. Eu não imaginava que tinha pessoas que faziam esse trabalho tão maravilhoso. Eu não imaginava mesmo! (...)

Esse projeto do GENPEX não tem igual, aqui pro DF é primordial, espero que eles (movimento popular) e vocês continuem né, o DF alfabetizado também, então pra mim é uma coisa assim muito boa, uma coisa que deu certo, que as pessoas fazem por amor, né... é porque é pela causa, pela luta.

Esse trabalho da forma que é feito pelo CEDEP e todo mundo junto é extremamente importante e fico feliz de poder aprender junto.

O primeiro saber reconhecido nessa avaliação do docente é o saber que Freire define como "o querer bem aos educandos". Segundo Freire (1996), o docente que adota essa postura, precisa estar aberto a querer bem e a gostar de querer bem, não somente um querer bem por si só. É preciso muito cuidado quanto às interpretações de Paulo Freire, pois ele nesse sentido não afirma que o professor deve pautar-se apenas 
neste saber e querer bem a todos. Trata-se de ter uma afetividade que faça o docente gostar de selar o compromisso com os educandos.

Freire (1996) diz claramente que a afetividade não se acha excluída da cognoscibilidade, mas faz uma observação quanto a ela:

O que não posso obviamente permitir é que minha afetividade interfira no cumprimento ético do meu dever de professor no exercício de minha autoridade" (p.160).

$\mathrm{O}$ fato de o professor ter afetividade com os sujeitos não afasta o conhecimento científico e não afasta a autoridade que ele precisa ter para discernir seu papel ético universal nos fazeres docentes. Nesta fala, a palavra "amor" foi exaltada demonstrando que a dimensão da afetividade e da luta vista na parceria entre movimento popular e universidade foi um aspecto que tocou a subjetividade do docente.

D2: Eu me formei numa faculdade privada né, comecei lá e terminei aqui então assim, e... era semipresencial, então não tinha muito debate, não tinha isso que o GENPEX faz aqui, era bem conteúdista, então...agora interagindo com a universidade por meio do GENPEX, agora que to tendo oportunidade de viver, é ótimo pra mim, to gostando muito desse debate!! A parceria enriquece (...)

Lá na hora assim é muito debate, muita reflexão, que fazemos na hora. Isso muda nossa visão, muitas vezes, nossa forma de pensar, de lidar com aquele assunto: é mesmo? Eu não tava pensando nisso, realmente. Aí você pesquisa, você já corre atrás de um outro meio de entrar naquele assunto, na forma de abordar. Então eu vejo como muito importante a forma como é trabalhado lá. Não algo sistemático em que cada um lê um texto e pronto. Não, é diferente.

Neste trecho, o docente aponta sua ressignificação para a questão do debate fervoroso em sala e para a pluralidade de ideias que desperta para a reflexão do que é diferente, prática que ele não presenciou nas trajetórias passadas. O segundo saber reconhecido nesta significação vai ao encontro do saber que Freire chama de “disponibilidade para o diálogo". Quando o docente diz: é mesmo, eu não estava pensando nisso, realmente... ele está deixando de afirmar que sabe tudo e se abre para o diálogo, revisão daquilo que ele já sabe e novas ideias ou questionamentos. Para Freire a verdadeira segurança é justamente quando existe uma convicção de que o educador já sabe algo mas que também ignora algo. Se existe a consciência da ignorância, ou seja, 
da inconclusão do sujeito, e a disponibilidade para o diálogo, o educador pode vir a saber melhor e conhecer o que ainda não sabe.

O docente D3 é o mais antigo na escola e já estava presente quando o GENPEX começou a atuar, nesse sentido, ele afirma:

D3: Quando a UnB chegou aqui na escola provavelmente pensei que vocês só queriam coletar dados. Porque o que acontece na universidade é isso. Não deveria ser, mas é. Ela pega dados e vai embora. Vocês continuaram,e com toda certeza o projeto teve mudanças, da fase inicial pra cá. Quando eu trabalhei em outra escola, eu recebi uma equipe do curso de odontologia que solicitou uma lista completa com dados dos meninos, e pensei: PERAI?! Não terá contrapartida? E eu defendo a minha escola, meus meninos, não vou permitir que tirem sarro deles.

Considerando que o projeto acontece dentro da extensão universitária, um dos tripés das universidades, uma forte crítica quanto ao contato da universidade com a escola aparece nesta fala: a prática de enxergar a escola como uma mera produtora de dados de pesquisa. Os apontamentos deste docente, defendem a permanência da extensão numa relação sólida de transformação escolar e a capacidade de intervenção que esta permanência pode trazer. Para ele, a relação que o GENPEX construiu nesta escola vai além de uma pesquisa descritiva que pratica coleta de dados.

Como práxis, durante a realização da Semana Universitária, anualmente, é a hora de celebrar esta relação, os discentes e docentes da escola visitam a Universidade e compartilham conosco o momento de rever e discutir nossa ação reafirmando a proximidade anual com a escola. A significação presente nesta fala, foi de que há uma relação de conhecimento, ambos conhecem o espaço um do outro e os espaços se tornam comuns.

O caráter permanente e contínuo da extensão alimenta a crença numa universidade atuante que se entrelaça e se compromissa com o desenvolvimento do que se dispõe a fazer. Portanto, o terceiro saber reconhecido apontado pelo professor nesta análise é chamado por Freire como o "comprometimento". O docente exaltou o compromisso dessa proposta que permanece. O comprometimento na visão de Freire, exige aproximar cada vez mais o que se diz do que se faz, independente de qual ideologia se optar. Sim, porque a educação para Freire não é neutra, sempre haverá uma 
ideologia regente. O que ele defende é que o professor não pode exercer atividade de magistério como se nada ocorresse com ele:

Minha presença de professor não pode passar desapercebida para os alunos e para a escola, a presença é em si política. Enquanto presença, não posso ser um sujeito de omissão, mas sim de opções. Devo revelar aos alunos, minha capacidade de analisar, comparar, avaliar, decidir, optar, e romper (...) (p.110)

A proposta é conhecida na escola. Todas as pessoas sabem de onde viemos e sabem como é o tratamento e abordagem que proporcionamos e construímos com estudantes e docentes. Portanto, o comprometimento de atuação do GENPEX foi uma significação importante na fala deste docente e vai ao encontro dos fundamentos de educação popular aqui defendidos.

O quarto e quinto saberes reconhecidos são, segundo Freire, (1996) a "reflexão crítica sobre a prática" e a "consciência do inacabamento". Ficou evidente que a abordagem popular da educação é uma novidade para os docentes envolvidos no projeto, pois apesar de possuírem formação pedagógica, ainda não tinham experimentado este viés. A necessidade de mudanças de pensamento e prática pedagógica ficou evidente nesta avaliação:

Eu entrei num grupo do EJA, e tô querendo participar de um encontro que terá no Piauí. Por isso que te falo, a EJA aqui abriu muito os meus horizontes, levou nesse ano de 2017 a tentar melhorar muito a minha prática, muito mesmo!

Eu acredito muito nessa tua geração, eu vejo por exemplo, amigos, ne que trabalham em escolas, recém formados, todos hoje em dia estão na SEDF e são caras bons, que tem assim sabe, compromisso, comprometimento, isso vem mudando, aquele ditado de EI DE VENCER MESMO SENDO PROFESSOR, que não estudava, que usava aquele mesmo caderno de faculdade pra dar aula, isso ainda existe, e tem gente assim, que usa aquele mesmo caderninho, que não pode virar uma folha que se desfaz, mas ainda continua dando aula nesse sentido. Continua fazendo educação nesse sentido.

Eu brigo o tempo todo pra mudar, pra pessoas mudarem onde trabalho, pra acompanhar a sociedade dinâmica, mas as pessoas não mudam. A gente faz reunião conversa, explica, mostra, a pessoa: legal, isso é muito bom , mas... não tem engajamento nenhum. 
A reflexão da prática acontece por meio de dois pensamentos: o pensamento ingênuo e o pensamento crítico. Freire alerta para a legitimidade destes dois pensamentos, pois os dois pensamentos dão origem a formas diversas de conhecimento, no entanto, o que se precisa possibilitar é que o pensamento ingênuo se vá tornando crítico aproximando-se epistemologicamente do sujeito. Dessa forma, o docente que já possui 4 graduações afirma que é necessário a mudança de práticas educativas, que partam do pensar sobre o fazer:

D1: As pessoas precisam mudar de prática e pensamento, porque se não mudar não chegam a lugar nenhum... e ver que a universidade age assim foi um esclarecimento, é você não saber que existe, de repente saber que acontece e e ver que você pode até participar junto, ne?!

O docente vai buscar então, por meio de formação e participação em evento científico, a melhoria de sua prática. Tem-se aí uma significação trazida pelo novo, que foi acolhida e que estimulou o docente a ampliar seu conhecimento. Para Freire o professor é um aventureiro responsável:

Como professor crítico, sou um aventureiro responsável, predisposto à mudança, a aceitação do diferente (p. 55)

O docente também diz acreditar na geração atual, na geração que faz o diferente, que está sempre buscando. É o que vai ao encontro da consciência do inacabamento. Esta consciência é o próprio ponto fundante dos seres humanos. A invenção da existência segundo Freire (1996) contando com o suporte e com a linguagem tornou o mundo inteligível e com ele a comunicabilidade. Nesse processo, assim como se fez a existência, o destino é algo a se fazer, a se transformar, a se modificar.

Em outro momento da entrevista, pergunto à D2:

P: Se um dia você não for mais professora e não der mais aula? Será que o que você aprendeu nessa relação com o GENPEX terá impacto na sua ação? D2: Sim, com certeza, é algo que fica pra vida. Considero um processo formativo, eu gosto muito. 
Este pequeno trecho apesar de curto, foi assertivo. A ação realizada tem impacto formativo para o docente e isto ressalta a necessidade da união entre a universidade e escola, de uma união de fato que aja e desenvolva, e não que apenas colete dados como apontado por outro docente. Os impactos dessa ação imbuída de orientação popular apesar de não estar realizando apropriação diretamente conceitual, inicia sem dúvidas uma experiência que estimula a busca pelo conhecimento e pela reformulação de novas práticas. Além disso, como explicitado transpassa os limites da sala de aula reconfigurando a prática docente num processo formativo para discente e docente ao mesmo tempo.

\section{B) DIMENSÃO TRANSFORMADORA: QUANTO ÀS TRANSFORMAÇÕES PERCEBIDAS NOS DISCENTES (EXTERNAS)}

Durante as entrevistas de D1 e D3 foram explicitados alguns vestígios de como os discentes se comportam quando a equipe do GENPEX assume os trabalhos tanto em sala quanto no laboratório de informática:

\footnotetext{
P: Você já me relatou algumas dessas mudanças, mas que tipo de mudança principal você vê no sujeito da EJA quando se adota uma prática dessas com influencia da educação popular?

D1: Eu acho que eles se interessam muito mais, porque se fala de uma realidade que é realidade dele, então quando você traz a história do Paranoá pra dentro da escola, por exemplo, você elabora um texto sobre o Paranoá, sobre alguma coisa relativa, quando se faz um mapa, por onde ele passa, qual caminho que ele percorre, o que tem na rua, os elementos... aí se trabalha a realidade deles.

Então ele vem pra cá com muito mais interesse! Você não ta mostrando pra ele só a cidade do Rio de Janeiro, Paris, você tá partindo daqui, da realidade dele, de elementos que ele conhece, não adianta ele ficar olhando e ele não saber o que que é aquilo, então você tem que trabalhar com ele o que tá dentro dele.
}

O sexto saber reconhecido neste trecho é definido por Freire como "respeito aos saberes dos educandos". Este saber é necessário para que se discuta com os estudantes a realidade social que vivem, porque estes sabem com propriedade. Segundo Freire:

Por que não discutir com os alunos a realidade concreta a que se deva associar a disciplina cujo conteúdo se ensina, a realidade agressiva em que a violência é constante e a convivência das pessoas é maior com a morte do 
que com a vida? Porque não estabelecer uma necessária "intimidade" entre os saberes curriculares fundamentais aos alunos e a experiência social que eles tem como indivíduos? (1996, p. 33 e 34)

A significação trazida por este docente é primordial para a educação emancipadora, para uma educação que parta do local para o global, pois ao estabelecer conexões próximas estimula-se a capacidade de fazer conexões maiores e, não é exatamente por isso que nossa existência clama? Não sobreviveremos de forma amistosa caso não superarmos os problemas sociais e ambientais que nos cercam.

As significações mais apontadas no tratamento aos discentes foram neste sentido, da proximidade com a realidade deles. Ainda nessa perspectiva de se trabalhar a realidade imediata dos estudantes, D3 aponta para a efetividade da configuração atual do projeto:

D3: Agora sim, o que vocês na informática é o que precisa ser feito, é mostrar que aquele botão liga, clicando em tal lugar desliga, e não que aquilo é um bicho de sete cabeças. Eles tem que ver que aquilo funciona, que aquilo não vai morder. Precisam de um aprendizado mais prático, que seja útil para a vida deles, que seja transformador, e na informática eles precisam rever o que estão aprendendo em sala e vocês fazem isto, melhorou muito.

Com base nas considerações feitas até aqui quanto aos saberes explicitados, é possível afirmar que os docentes estão ressignificando suas práticas e pensamentos pedagógicos ainda que sem aporte teórico específico a partir da construção de saberes docentes fundados na experiência prática. $\mathrm{O}$ que não significa que não haja ciência nos depoimentos que deram. O que acontece é que no tocante à EJA os saberes demonstrados são provenientes de um saber de experiência adquirido juntamente à prática realizada pelo GENPEX. A EJA tem esse caráter autodeclaratório. É um público que mostra suas especificidades, um público latente quanto às questões profissionais, de gênero, etnia e outras. Não há como atuar na EJA e não se afirmar esse caráter, pois ela mesma diz ao ambiente escolar suas próprias constituições, dificuldades e perspectivas. Quanto à formação docente, ainda demanda um aprofundamento teórico. Porém neste trabalho, o movimento percebido aponta uma ausência de formação específica para atuação com este público, mas que tem sido atenuada pela aproximação 
com a práxis da universidade e da interação com membros do movimento popular. $\mathrm{O}$ que está acontecendo é uma formação NO ato de educar.

No tocante à participação dos docentes, a configuração atual do projeto, permite que o GENPEX permaneça simultaneamente nos dois horários na sala de aula e também no laboratório de informática. Pelo menos em um dos horários, a equipe de estudantes do GENPEX encontra e atua junto ao docente, uma vez por semana para cada turma.

A rotina de um docente noturno está organizada em 4 dias para a regência e um dia de coordenação. Neste momento de coordenação, o tempo é utilizado para fazer registros de notas, elaboração de relatórios e planejamentos pertinentes à rotina da sala de aula, o que não possibilita a entrada fixa do GENPEX na elaboração do planejamento. O grande desafio do grupo agora é encontrar tempo necessário para agregar ainda mais esses professores na construção do planejamento semanal que já é realizado na UnB. O desafio é encontrar tempo e estratégias de reunir-se com o professor para afinar as propostas de intervenção e abordagens.

Com objetivo de realizar construção coletiva para proporcionar o sentimento de pertencimento às ações, a postura assumida pelo GENPEX é de que não é apenas a universidade que detém o conhecimento, mas que o conhecimento do chão da sala é também legitimado e valorizado de forma horizontal dentro desta perspectiva popular, e os professores... Ah, estes tem muito mais conhecimento do chão da sala com relação à maioria dos integrantes do GENPEX, pois estes ainda estão em processo de formação para o exercício docente.

Como parte fundamental do universo escolar e do planejamento, a aproximação com os docentes é um aspecto que se tem buscado ampliar. Atualmente o planejamento das atividades na escola acontece de duas formas: no início do semestre, com uma reunião para proposição de temática a ser abordada feita com a coordenação, e reunião do GENPEX na UnB para organizar quais estudantes irão realizar estágio, quais horários, recursos necessários e encaminhamentospara a realização da proposta. A segunda forma é o planejamento semanal, que começa no ato. São reuniões desdobram a proposta norteadora-maior delimitada no início do semestre após conhecer o público e as demandas. É no ato, com base nas sensações e percepções que docentes e membros do GENPEX tem da rotina da aula, que o planejamento começa a acontecer. São feitas 
anotações, sugestões, comentários, considerações durante as aulas, e no planejamento semanal realizado na $\mathrm{UnB}$, são traçadas as propostas com base em todos os registros.

Todos os registros se transformam posteriormente no relatório final de estágio supervisionado de cada graduando. Este ainda é um aspecto a se desenvolver, está em constante indagação. Portanto, a aproximação com o corpo docente já acontece, obtivemos avanço na participação das aulas e na participação dos docentes no laboratório de informática, mas a dificuldade em constituir um horário determinado para afinar propostas, debater ideias, propor metodologias e formas de abordagem na sala e informática ainda precisa ser articulada na medida em que a estrutura escolar for sendo reconfigurada.

No período de realização deste trabalho, o GENPEX foi convidado a participar da reunião pedagógica que acontece em fevereiro, no início do semestre e que norteia a ação da escola. A intenção da coordenação que acolhe o projeto é englobar o GENPEX no desenvolvimento da escola junto ao corpo docente. Esta é uma oportunidade que caminhará para o estreitamento desses laços.

Para analisar as ressignificações atribuídas à participação dos docentes no planejamento e execução de atividades com o GENPEX, foi perguntado:

P: $O$ que significa para você planejar e executar atividades/projetos juntamente ao GENPEX?

D1: Ah, é ótimo! Porque por exemplo: Ah quero trabalhar com museu, como as próximas atividades serão... Ai a gente vai propondo estudarpor exemplo nome dos alunos, a origem... A Julieta (membro do Genepx) sugere alguma coisa, cada um vai sugerindoe a gente vai construindo juntos, ai digo: oh Julieta por que que a gente não trabalha receitas? De bolo, de chá, de remédio... porque todo mundo tem um conhecimento muito grande, eles tem uma bagagem muito grande.

Eu costumo mostrar isso muito pra eles: ah mas eu não sei fração... quer dizer: claro que sabe!

Você não sabe botas meia xícara de farinha de trigo, você não Sabe fazer um traço de massa, vocênão sabe botar 1 lata de cimento, 1 de areia e um pouco de água? Então você sabe!! Você só não conhece o conceito, você não sabe ainda organizar o conceito, masvocê conhece fração. Então a experiência deles nesses planejamentos conta demais, eu vejo aí que a gente tem que aproveitar ele. Então eu troco com a Julieta nesse sentido, hoje mesmo eu quis trabalhar palavras dentro de palavras ex: BRASILEIRO. Sai o quê? Sai Brasil, sai lei, sai não sei o quê... Então vamos jogando isso com eles e eles aprendem muito rápido.

Então nesse planejamento traz muitas ideias. 
Ao usar exemplos dos saberes dos educandos, o docente faz o exercício do respeito ao saber de experiência feito, conceito defendido por Freire, em Pedagogia da Esperança (1997). Freire afirma ter tido uma convivência respeitosa com estes saberes advindos da experiência popular quando esteve no Nordeste do Brasil, e segundo ele quando vivenciou o chamado senso comum, sua postura nunca foi de desdenhá-lo ou de minimizá-lo, pois:

Se não é possível defender uma prática educativa que se contente em girar em torno do "senso comum", também não é possível aceitar uma prática que, zerando o saber de experiência feito, parta do conhecimento sistemático do (a) educador (a). (1997, p. 31- 32)

O autor não defende a permanência de apenas uma postura. Isto chama a atenção. Não defende a ignorância e estabilidade do senso comum, tampouco o desrespeito quanto às trajetórias dos educandos. D1 demonstra assertividade com esta ideia de Freire, logo no ato de planejar junto ao GENPEX, e assim o pratica quando faz o aluno perceber que ele sabe, porém de outra forma aplicada, assim como ele diz: eles aprendem muito mais rápido! Importante destacar que Freire aponta para que aconteça a superação do senso comum, seja necessário passar por ele, não ignorá-lo. É necessário partir dele e não ficar nele.

Em outro momento, pergunto à D1:

P: E no laboratório de informática? O que você pensa sobre o planejamento das atividades de lá?

D1: Acho legal porque trocamos muitas ideias, a gente faz isso junto, e a informática alfabetiza muito bem porque o aluno imerge nas teclas, ele tá vendo as teclas, ele tá vendo as letras também, apesar de que ás vezes ele só olha para o teclado ou só pra tela. Mas o negocio é construir...

A aula de informática a gente participa, também, o professor tá dentro. A gente tá lá dentro, ao mesmo tempo que o GENPEX vai trabalhando a gente vai sugerindo: olha pra ele ler isso aqui, é melhor assim, é dessa forma, corrige isso. Tá entendendo?

Ao considerar os conhecimentos dos estudantes no planejamento, novamente o saber voltado para o respeito ao saber do educando (FREIRE, 1996), aparece. O sétimo saber que aparece aqui, que é reconhecido nesse ato de planejar coletivamente, é o “saber escutar". O saber escutar na concepção de Freire, deve respeitar a condição de 
que" não é falando aos outros de cima para baixo que aprendemos a escutar, mas é escutando que aprendemos a falar com eles". (p.127)

Somente quem escuta pacientemente e criticamente o outro é que é capaz de falar COM ele e não para ele. A horizontalidade do falar com não está somente nas aulas realizadas com os docentes mas principalmente no ato inicial de planejar, o que sustenta outro argumento de Freire: é necessário fazer o que se fala. A escuta está presente desde a prática diária em sala de aula com os estudantes, porque não estaria no planejamento entre os membros e docentes?

Diante do papel de autoridade que um docente tem, por vezes ele pode adotar uma fala impositiva. Mas segundo o autor, o professor deve até mesmo nesses momentos enxergar o outro como sujeito de uma fala crítica e não somente como um objeto de discurso.

Cabe aqui fazer uma distinção entre a autoridade e o exercício da escuta. A autoridade está arrolada a responsabilidade que um professor tem que gerir, conduzir, guiar a turma, e esta deve ser muito bem executada. O exercício da escuta é respeitar e considerar as indagações de cada um. Um não anula o outro. Um professor pode ter autoridade e exercer muito bem a escuta, respeitando as condições dos estudantes e inclusive de pessoas que convivem com ele em qualquer dos contextos.

A valorização da diversidade de ideias, não aderindo uma só verdade, foi uma assertiva nas falas de D1, D2 e D4:

D1: Esse planejamento, esse ato de planejar a aula junto com GENPEX é muito importante porque são onde se encontram né, os dois viés: professor e universidade....

D2:Sim, acho que significa a união de ideias que acabam gerando outras, várias pessoas, várias ideias, isso torna a aula muito melhor. Quando tem uma pessoa que pensa assim: só ela que sabe, só ela que vai dar a melhor aula, pensar sozinha, não acho que é assim.. tem que ser junto, é super importante.

D4: Tem sido interessante, pois também estou aprendendo a lidar com esta modalidade, aprendo coisas específicas do mundo de adultos e idosos.

Neste outro trecho D2, sugere formas de aproximação com a universidade que envolvem planejamento e compartilhamento de conhecimento:

Eu acho que a aproximação tá indo bem, eu acho que vocês podiam ajudar mais a gente com atividades sobre como abordar temas sociais, materiais, 
etc, trazer mais sugestões. Seria bom um planejamento presencial, mas não dá tempo. O grupo poderia trazer, eu pesquiso muito e não acho, é difícil achar atividade voltada pra adulto. Acho que vocês poderia indicar leituras também.

Pode-se concluir que a participação dos docentes tem sido em sala de aula e na elaboração de planejamentos primários, além de conversas em grupo de docentes de rede social, meios que aproximam os membros unificando a relação. Esta forma de participação tem sido gradual, assim como foi descrita na configuração inicial e atual no início deste capítulo e como dito, esta aproximação está acontecendo. Foi diante desta experimentação de uma reconfiguração que surgiu a necessidade de compreender as possíveis ressignificações dos docentes até o momento.

A discussão realizada até aqui tratou de um processo de modificação didáticopedagógica para a Educação de Jovens e Adultos, um processo de mesclar educação popular com educação escolar. Também foi perguntado aos docentes sobre a possibilidade da mudança do modelo atual para um modelo de EJA escolar que fosse pautado nas contribuições da educação popular, na tentativa de vislumbrar modificações em outras escolas. Todos sinalizaram de forma positiva:

D1:Claro, eu acho que essa na verdade é a proposta original de uma escola, a proposta da educação envolve a parte formal, informal, território, espaços, a comunidade, e o GENPEX articula isso muito bem. Isso devia ser regra em várias escolas, é porque é assim que funciona dentro da história da comunidade você trazer a escola pra comunidade e a comunidade pra escola, né? (...)

Essa avaliação revela a ideia original de uma escola na concepção de D1. O docente diz que na verdade esse deveria ser o papel de uma escola, a articulação com a comunidade. Na avaliação dele ambos tem muito que se complementar. Fica evidente o primeiro e segundo aspecto de aplicabilidade da proposta que seria a articulação com a comunidade e mais tempo para organização e prática. Desafio relacionado ao sistema educacional tradicional que afasta essa possibilidade de articulação, principalmente no período noturno e compactado, condições em que a EJA escolar ocorre:

O GENPEX faz essa relação muito bem feita, tanto é que tá aí uma realidade aqui dentro da escola 03, né?! Tá acontecendo...mas acho que o tempo 
deveria ser aumentado também, é pouco tempo. Na verdade é menos de 6 meses que temos pra trabalhar.

D2 aponta o terceiro aspecto de aplicabilidade da proposta: a presença do movimento popular dentro da escola. Além de afirmar o aspecto do tempo que D1 também afirmou , D2 assinala que seriam necessárias pessoas do movimento popular, engajadas na causa para que a proposta acontecesse em outras escolas de EJA. Nesse sentido, o docente deixa clara a importância do movimento popular na emancipação dos estudantes, característica do movimento popular atuante nesta cidade:

D2: O GENPEX é um dos incentivadores de mudança, o problema é que não dá pra ser diário né. Eu acho que o bom seria se houvesse disponibilização de pessoas pra ajudar a modificar isso em sala... Seria possivel acontecer em outras escolas, se houvessem pessoas disponiveis. E essa atuação não deveria só na informática, existem muitos alunos com dificuldade que precisam de um olhar atento, e se houvessem pessoas do movimento popular também pra ajudar a gente seria bom, um dia na informática acho pouco.

Agora pra multiplicar precisaria de um movimento popular em cada cidade, poderiam reunir professores e pessoas engajadas pra começar essa ação nas outras escolas.

Para vislumbrar uma reconfiguração da EJA é necessário pensar a respeito dos indicadores que nos levaram a este posicionamento. Segundo Arroyo (2005), vários são os indicadores que apontam um novo momento para a EJA. Entre eles: a configuração como um campo específico de políticas públicas, de formação de educadores, de produção teórica e de intervenções pedagógicas.

Apesar de esta notoriedade da EJA estar crescendo, a reconfiguração que se tem experimentado não acontecerá de forma simples, assim diz Arroyo (2005):

Todo esse conjunto de indicadores aponta que estamos em um momento novo, que exige como primeira estratégia a reconfiguração da EJA. Entretanto essa reconfiguração não virá espontaneamente. O sistema escolar continua a pensar em sua lógica e estrutura interna e nem sempre tem facilidade para abrir-se a essa pluralidade de indicadores que vem da sociedade, dos próprios jovens-adultos e idosos e de outras políticas públicas. (p. 22) 
Sabemos que a modificação de uma estrutura escolar leva tempo e condições estruturais fortes. Mas a pluralidade da EJA tem mostrado historicamente a quem ela serve e como ela é feita. Além da mudança estrutural, a mudança de pensamento caminha paralelamente a esta reconfiguração. Pensamento e saberes docentes contribuem fortemente e subjetivamente para a reconfiguração de um EJA que assuma verdadeiramente a condição de seus sujeitos.

\section{CONSIDERAÇÕES FINAIS}

É objetivo da educação proporcionar formação integral aos estudantes e reconhecê-los como sujeito de direitos. Após a luta pela conquista do direito, a segunda fase é promover meios para que este direito seja reafirmado e garantido. É grande o avanço da inscrição da EJA como modalidade ofertada pelo estado em lei, porém o público diversificado apresenta demandas nítidas, inegáveis. A escola por estar diariamente mais próxima deste grupo precisa acolher tais demandas, atuando como um braço mediador que também afirma o direito do educando.

A proposta de interação entre o modelo formal de EJA e uma prática baseada na educação popular nesta escola, é uma experiência desafiadora que visa promover a qualidade da prática na tentativa de promover a permanência dos estudantes e efetivação dos direitos a nível micro, através de aspectos didático-pedagógicos diários que reverberam nos sujeitos envolvidos. Para que esta proposta se valide, é necessário reconhecer anteriormente toda a contribuição deixada pela educação popular ao longo da história, além de desvelar o real sentido e vocação de educação popular e superar a ideia de uma educação informal voltada somente para a classe pobre. A educação popular é flexível, deve e pode estar nos diversos espaços para dar voz aos sujeitos, ensinar o diálogo e a construção respeitosa de decisões e mudanças justas e horizontais.

A presença da educação popular não envolve apenas um grupo específico. $\mathrm{O}$ alcance e a potencialidade dela são imensuráveis. Onde ela se insere, impacta em todos os sujeitos, seja de forma tímida e gradual ou de forma desinibida, de alguma forma, ouvir a voz dos sujeitos interferirá nos processos formativos, principalmente de quem é silenciado pela ausência de conhecimento propriamente científico.

Nesse sentido, toda prática que envolva discentes está intimamente ligada aos docentes. Portanto, a necessidade de agregar os professores e fazê-los parte do processo 
ouvindo suas avaliações e analisando as mudanças subjetivas, se faz necessária, pois é impossível separar a subjetividade do processo de ensinar. É essa subjetividade que vai conscientemente ou insconscientemente impactar na prática com os estudantes e na prática do docente com ele mesmo.

Com base nesta avaliação, pode-se compreender como os docentes analisam a interação desses dois modelos. Pode-se considerar que o corpo docente tem ressignificado seus pensamentos e práticas por meio da construção de saberes implícitos em suas falas, ainda que sem conhecimento teórico de educação popular. Esta demonstração dos saberes que foram aqui descritos deixam evidente a força e capacidade da população ensinar sua essência aos profissionais que lidam com ela. Todos os saberes encontraram sustentação teórica nas obras de Freire. Deixam evidentes também a capacidade de os profissionais agregarem esta essência e buscar a transformação, modificação, aperfeiçoamento de seu saber-fazer. Além disso, sinalizam como uma proposta de educação possível de acontecer em outros espaços educacionais.

Esta análise demonstra a necessidade de reestruturação de propostas começando com a experimentação, valorizando as dinâmicas e comportamentos da própria população, construção, diálogo, estudos e pesquisas, para que se possa vislumbrar uma EJA mais próxima do que o público anseia.

Em se tratando de uma educação com tamanha diversidade como EJA, é impossível não pensar no diálogo e flexibilização do sistema disciplinar e tradicional vigente. É papel da escola, repensar sua estrutura, adequar, se questionar e abrir-se a novas perspectivas que podem acontecer por meio do contato com a Universidade, mas não exclusivamente. É essa abertura que semeará a formação de sujeitos em sua totalidade, partindo do principio humano e sócio-crítico de educação. 


\section{PARTE III - PERSPECTIVAS PROFISSIONAIS E PESSOAIS}

Com todo este caminho trilhado até aqui, pegarei o conhecimento e as possibilidades de mudança registradas neste trabalho, e levarei para qualquer espaço em que eu esteja. Tenho interesse em utilizar a essência da educação popular e trabalhar no contexto da educação básica, especificamente com a EJA escolar. Acredito que a vida saiba onde exatamente me encaixar nos próximos anos. Obrigada a todos os docentes participantes por se abrirem ao pensamento e ação popular. 


\section{REFERÊNCIAS:}

ARROYO, M.G. Educação de jovens e adultos: um campo de direitos e de responsabilidade pública. Diálogos da educação de jovens e adultos. Belo Horizonte, Minas Gerais: Editora Autêntica, 2005.

BRANDÃO, C. R; MACHADO, M. M. (Org.). Formação de educadores de jovens e adultos. II Seminário Nacional. A educação popular e a educação de jovens e adultos: antes e agora. Secad, Ministério da Educação, 2008.

Companhia de Desenvolvimento do Distrito Federal: PESQUISA SOCIOECONOMICA - PESQUISA DISTRITAL POR AMOSTRA DE DOMICÍLIOS,PARANOÁ..Disponível em: http://www.codeplan.df.gov.br/images/CODEPLAN/PDF/pesquisa_socioeconomica/p ad/2015/Apresentacao_PDAD_Paranoa.pdf>. Acesso em: 5 de set. 2017.

Conselho Nacional de Educação - Ministério da Educação. Diretrizes Curriculares Nacionais para a Educação de Jovens e Adultos. Brasília, DF: 2000. Disponível em: $<$ http://portal.mec.gov.br/secad/arquivos/pdf/eja/legislacao/parecer_11_2000.pdf $>$ Acesso em 8 de outubro de 2017.

FREIRE, P. Pedagogia da Autonomia, saberes necessários à prática educativa. São Paulo: Ed Paz e Terra, 1996.

FREIRE, P. Pedagogia da Esperança, um reencontro com a Pedagogia do oprimido. Rio de Janeiro. Ed. Paz e terra, 1992.

GIL, Antônio Carlos. Métodos e técnicas de pesquisa social. 6. ed. - São Paulo : Atlas, 2008.

GIOVAnETTI, M. A. G. C. A formação de Educadores da EJA: O legado da educação popular. Diálogos da educação de jovens e adultos. Belo Horizonte, Minas Gerais: Editora Autêntica, 2005.

Instituto Brasileiro de Geografia e Estatística - Síntese de indicadores sociais: Uma análise das condições de vida da população brasileira. Rio de Janeiro, n. 36, 2016. Disponível em: <https://biblioteca.ibge.gov.br/visualizacao/livros/liv98965.pdf> Acesso em 16 de setembro de 2017.

Instituto Nacional de Estudos e Pesquisas Educacionais Anísio Teixeira. Notas estatísticas, Censo Escolar, 2016. Brasília, DF, fevereiro de 2017. Disponível em: <http://download.inep.gov.br/educacao_basica/censo_escolar/notas_estatisticas/2017/no tas_estatisticas_censo_escolar_da_educacao_basica_2016.pdf > Acesso em: $20 \mathrm{de}$ outubro de 2017.

Lei distrital n. 4.751, de 7 de fev. de 2012. Lei de gestão democrática do sistema de ensino público do Distrito Federal. Brasília, DF. fev de 2017. Disponível em: <http://www.buriti.df.gov.br/ftp/diariooficial/2012/02_Fevereiro/DODF\%20N\%C2\%B 
A\%20029\%2008-02-2012/Se\%C3\%A7\%C3\%A3o01-\%20029.pdf> Acesso em: 01 de setembro de 2017.

MACHADO, M. M. A educação de jovens e adultos após 20 anos da Lei n. 9.394 de 1996. Revista Retratos da escola, v. 10, n. 19, dez de 2016. Disponível em: <http://retratosdaescola.emnuvens.com.br/rde/article/viewFile/687/706> Acesso em: 21 de novembro de 2017.

Ministério da Educação. Programa Nacional de Tecnologia Educacional (ProInfo). Disponível em: <http://portal.mec.gov.br/proinfo>Acesso em: 10 de novembro de 2017. NAVES, R. R. (Org.) Formação de professores: ação-reflexão-inovação. Brasília, DF: Editora Universidade de Brasília, 2015.

OLIVEIRA, M. K. de.; Jovens e adultos como sujeitos de conhecimento e aprendizagens. Faculdade de Educação, Universidade de São Paulo. Revista Brasileira de Educação, setembro de 1999.

RIBEIRO, Paulo Rennes Marçal. História da educação escolar no Brasil: notas para uma reflexão. Paidéia (Ribeirão Preto), Ribeirão Preto , n. 4, p. 15-30, Julho de 1993. Disponível em: <http://www.scielo.br/scielo.php?script=sci_arttext\&pid=S0103863X1993000100003\&lng=en\&nrm=iso>. Acesso em: 06 outubro de 2017.

Secretaria Geral da Presidência da República. Departamento de Educação Popular e mobilização cidadã. Marco de Referência de Educação popular para as políticas púbicas. Brasília, DF: 2014.

SOARES, L.; GIOVANETTI, M. A; GOMES, N. L. (Org.) Diálogos da educação de jovens e adultos. Belo Horizonte, Minas Gerais: Editora Autêntica, 2005.

Soares, Leôncio J. G.; Soares, Rafaela C. e S.(2014). O reconhecimento das especificidades da Educação de Jovens e Adultos: constituição e organização de propostas de EJA. Arquivos Analíticos de Políticas Educativas, 22 (66). http://dx.doi.org/10.14507/epaa.v22n66.2014. Dossiê Educação de Jovens e Adultos. Editoras convidadas: Sandra Regina Sales \& Jane Paiva

SOBRAL, J. B. L.; REIS,R. H. dos.; Ação-reflexão-ação em uma escola pública do Paranoá - Distrito Federal: Uma perspectiva de Educação Popular na Educação de Jovens e Adultos. Brasília, DF: Secretaria de Educação do Distrito Federal, Cadernos RCC, v. 4, n. 2, maio de 2017.

TARDIF, M. Saberes docentes e formação profissional. Petropólis, RJ: Vozes, 5 Ed. 2002.

VIEIRA, M. C. Fundamentos históricos, políticos e sociais da Educação de Jovens e Adultos. Brasília, Universidade de Brasília: Centro de Educação à distância CEAD/UnB, v. 1, 2004. 
VIEIRA, M. C.; REIS, R. H. dos; SOBRAL, J. B. L.; Educação de Jovens e Adultos como ato de amor, poder e saber. Brasília, DF: Editora Universidade de Brasília, 2015. 


\author{
ANEXO 1 - ENTREVISTA SEMI-ESTRUTURADA \\ ROTEIRO DE ENTREVISTA
}

IDADE:

FORMAÇÃO ACADÉMICA:

CIDADE EM QUE RESIDE:

TEMPO DE ATUAÇÃO NA REDE PÚBLICA:

TEMPO DE ATUAÇÃO NA ESCOLA:

SITUAÇÃO FUNCIONAL?EFETIVO? CONTRATO TEMPORÁRIO

TEMPO DE ATUAÇÃO NA EJA:

ATUA EM OUTRO NIVEL DE ENSINO? QUAL? QUANTO TEMPO?

PARTICIPA OU JÁ PARTICIPOU DE MOVIMENTOS POPULARES?

ETAPA E DISCIPLINA LECIONADA:

1- PARA VOCÊ O QUE É A EDUCAÇÃO POPULAR ?

1.2 VOCÊ TEM EXPERIÊNCIA NESSA ÁREA?

2- PARA VOCÊ O QUE É A EDUCAÇÃO DE JOVENS E ADULTOS?

2.1- CONTE-ME UM POUCO SOBRE SUA EXPERIÊNCIA NA EJA? (ASPECTOS QUE A LEVARAM A SE INSERIR NESSA ÁREA)

3- COMO O TRABALHO DO GENPEX INTERFERE EM SUA PRÁTICA PEDAGÓGICA?

4- O QUE SIGNIFICA PARA VOCÊ PLANEJAR E EXECUTAR ATIVIDADES/PROJETOS JUNTAMENTE AO GENPEX?

5- NA SUA OPINIÃO, É POSSÍVEL REALIZAR MODIFICAÇÕES NO MODELO ATUAL DA EJA UTILIZANDO PRINCIPIOS DA ED POPULAR. COMO? 


\section{ANEXO 2 \\ TERMO DE CONSENTIMENTO LIVRE E ESCLARECIDO}

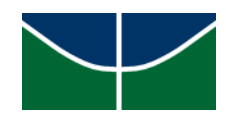

Universidade de Brasília

Faculdade de Educação

\section{TERMO DE CONSENTIMENTO LIVRE E ESCLARECIDO}

Você está sendo convidado(a) a participar, como voluntário (a), do estudo/pesquisa de monografia intitulado: A inserção da educação popular no contexto da educação de jovens e adultos: Visões do corpo docente, conduzida por Débora Oliveira Silva, matrícula 12/0157314, graduanda de Pedagogia e concluinte no semestre de 2017-2.

Este estudo tem por objetivo: Analisar em que medida a interação entre os modelos da EJA e da educação popular contribui para a ressignificação da visão docente acerca da prática pedagógica desenvolvida. Você foi selecionado(a) por fazer parte do corpo docente da EJA na referida escola e por experimentar uma organização diferente com perspectivas da Educação Popular. Sua participação não é obrigatória e a qualquer momento, você poderá desistir de participar e retirar seu consentimento. Sua recusa, desistência ou retirada de consentimento não acarretará prejuízo.

Sua participação nesta pesquisa consistirá em responder livremente ao questionário anexo, tendo as falas audiogravadas por celular pela pesquisadora, para transcrição e análise posterior de elementos revelados verbalmente.

Os dados obtidos por meio desta pesquisa serão confidenciais e não serão divulgados em nível individual, visando assegurar o sigilo de sua participação. O pesquisador responsável se compromete a tornar públicos nos meios acadêmicos e científicos os resultados obtidos de forma consolidada sem qualquer identificação de indivíduos ou instituições participantes.

Caso você concorde em participar desta pesquisa, assine ao final deste documento, que possui duas vias, sendo uma delas sua, e a outra, do pesquisador responsável / coordenador da pesquisa. Segue o telefone e o endereço institucional do pesquisador responsável: Faculdade de Educação da Universidade de Brasília, Asa Norte, Distrito Federal- telefone: 55 (61) 3107-6160.

Declaro que entendi os objetivos, de minha participação na pesquisa, e que concordo em participar.

Paranoá, DF, de de

Assinatura do(a) participante:

Assinatura do (a) pesquisador (a) : 